\title{
Hospital Energy Benchmarking Guidance - Version 1.0
}

Brett C. Singer

Lawrence Berkeley National Laboratory, Berkeley CA

Contributing Developers:

Paul Mathew, Steve Greenberg, Bill Tschudi, Dale Sartor (LBNL)

Susan Strom, Walter Vernon: Mazzetti Nash Lipsey Burch (San Francisco, CA)

\begin{abstract}
This document describes an energy benchmarking framework for hospitals. The document is organized as follows. The introduction provides a brief primer on benchmarking and its application to hospitals. The next two sections discuss special considerations including the identification of normalizing factors. The presentation of metrics is preceded by a description of the overall framework and the rationale for the grouping of metrics. Following the presentation of metrics, a high-level protocol is provided. The next section presents draft benchmarks for some metrics; benchmarks are not available for many metrics owing to a lack of data. This document ends with a list of research needs for further development.
\end{abstract}




\section{Acknowledgments}

The authors thank the many industry advisors and colleagues who provided helpful background information, comments, and suggestions to help advance the development of this first generation hospital energy benchmarking system. Special thanks go to Jeffrey Keyak of Kaiser Permanente and Clark Reed of the Environmental Protection Agency's Energy Star for Healthcare Program for their extensive comments and development advice. LBNL and M+NLB researchers are especially indebted to the Chief Engineer and engineering staff at the facility on which this methodology was first applied.

This work was supported by Building Energy Research Grant \#: 54920A/06-08B funded by the California Energy Commission, Public Interest Energy Research program, and supported by the Assistant Secretary for Energy Efficiency and Renewable Energy, Building Technologies Program of the U.S. Department of Energy under Contract No. DE-AC02-05CH1131.

\section{Legal Notice}

This report was prepared as a result of work sponsored by the California Energy Commission (Commission). It does not necessarily represent the views of the Commission, its employees, or the State of California. The Commission, the State of California, its employees, contractors, and subcontractors make no warranty, express or implied, and assume no legal liability for the information in this report; nor does any party represent that the use of this information will not infringe upon privately owned rights. This report has not been approved or disapproved by the Commission nor has the Commission passed upon the accuracy or adequacy of the information in this report.

\section{Disclaimer $^{1}$}

This document was prepared as an account of work sponsored by the United States Government. While this document is believed to contain correct information, neither the United States Government nor any agency thereof, nor The Regents of the University of California, nor any of their employees, makes any warranty, express or implied, or assumes any legal responsibility for the accuracy, completeness, or usefulness of any information, apparatus, product, or process disclosed, or represents that its use would not infringe privately owned rights. Reference herein to any specific commercial product, process, or service by its trade name, trademark, manufacturer, or otherwise, does not necessarily constitute or imply its endorsement, recommendation, or favoring by the United States Government or any agency thereof, or The Regents of the University of California. The views and opinions of authors expressed herein do not necessarily state or reflect those of the United States Government or any agency thereof or The Regents of the University of California.

\footnotetext{
${ }^{1}$ Disclaimer included verbatim as required by LBNL RPM Section 5.02.03. United State Government sponsorship refers to the management contract noted in the Acknowledgments. The specific work described in this report was funded by the California Energy Commission through a contract managed by the California Institute for Energy and the Environment, also noted in the Acknowledgments.
} 


\section{Table of Contents}

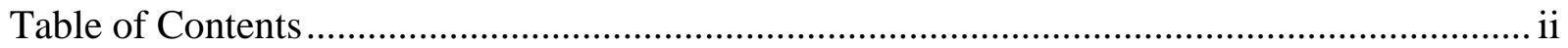

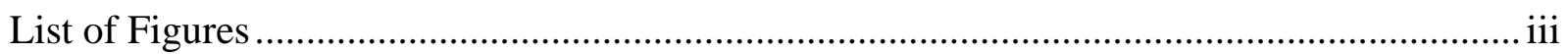

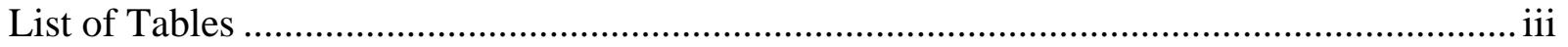

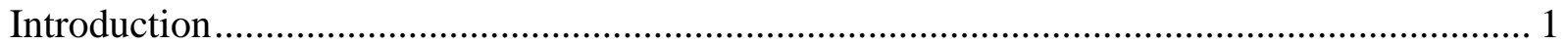

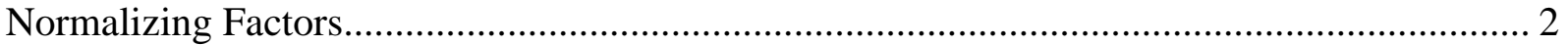

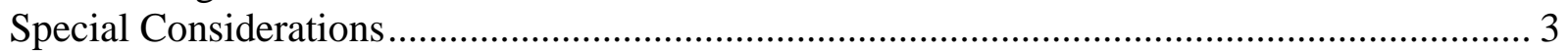

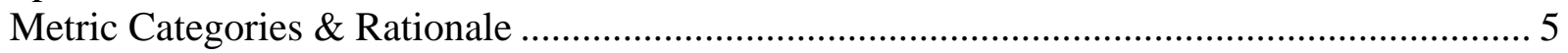

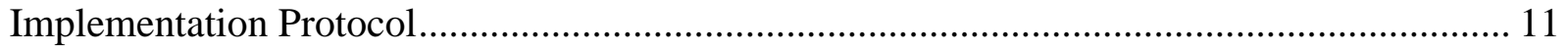

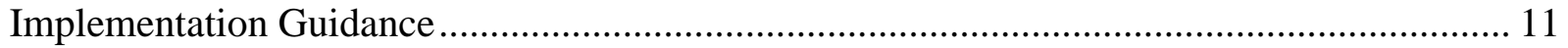

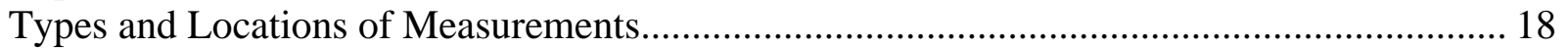

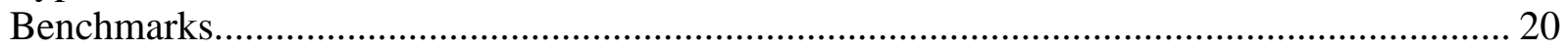

CEUS end-use estimates used to derive benchmarks ............................................. 22 


\section{List of Figures}

Figure 1. CEUS estimates for site energy intensity of California hospitals. .23

Figure 2. CEUS estimates for cooling source energy intensity of California hospitals. ............. 24

Figure 3. CEUS estimates for heating source energy intensity of California hospitals.............. 25

Figure 4. CEUS estimates for DHW source energy intensity of California hospitals................. 26

Figure 5. CEUS estimates for ventilation site energy intensity of California hospitals. .............. 27

Figure 6. CEUS estimates for lighting site energy intensity of California nursing homes.......... 28

Figure 7. CEUS estimates of ventilation efficiencies for California hospitals......................... 28

\section{List of Tables}

Table 1. Metrics for thermal and ventilation services provided to hospital.............................. 6

Table 2. Thermal and ventilation system efficiencies. ................................................... 7

Table 3. Metrics for hospital thermal and ventilation energy intensities................................. 8

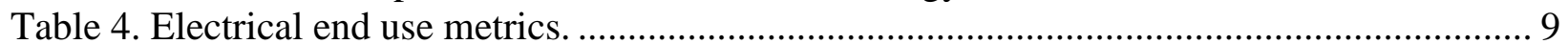

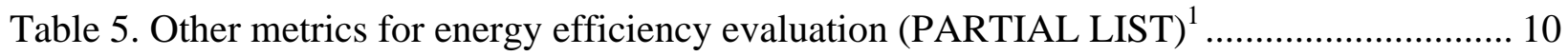

Table 6. Draft energy benchmarks for California hospitals................................................ 21

Table 7. Efficiency benchmarks for thermal and ventilation systems. .................................. 21

Table 8. Hospital energy performance metrics requiring benchmarks. ................................... 22 


\section{Introduction}

Benchmarking is an assessment approach in which energy-related metrics measured or estimated at one facility are compared to those from other facilities and/or specific performance targets. Metrics can be specified at the level of a facility, a building, a functional area within a building or specific systems or operations. Benchmarks can be derived from distributions of metric values obtained from facilities having similar functionality or characteristics, from engineering analysis or building simulation modeling, or from expert knowledge of standard and best practices.

Metrics should be developed to make comparisons among facilities as relevant and meaningful as possible. This is accomplished by limiting the comparison group (e.g., inpatient facilities that provide acute care services) or by use of metrics that are normalized or otherwise adjusted by essentially uncontrollable determinants of energy use. To account for the single most important determinant - facility size - total annual energy use is divided by the floor area to calculate energy intensity in units of thousands of British thermal units or watt-hours per square foot per year (kBtu/sf-yr or kWh/sf-yr). Other factors that have a first order effect on energy are climate, weather, operating schedule, and the suite of activities occurring within the facility. Accounting for these factors is discussed below.

The common starting point for facility benchmarking is energy use information from utility and fuel bills. These provide the cost and amount of each type of energy (electricity, natural gas, fuel oil, etc.) used at the site on a monthly basis. The next step is to identify the buildings served by each supply of energy, as described in more detail below. Assuming for the moment the simplest case of a hospital building with a dedicated central plant, the supplied energy (from utility bills) can be divided by floor area to calculate site energy intensities for electricity ( $\mathrm{kWh} / \mathrm{sf}-\mathrm{yr})$, all fuels including natural gas and oil (kBtu/sf-yr), and all forms of energy used on site (kBtu/sf-yr, obtained by converting electric energy into $\mathrm{kBtu}$ ).

Energy use intensity also should be framed in terms of source energy. Source energy recognizes variations in the amount of primary fuel energy required to deliver various forms of energy at the site. The key distinction is between electricity and primary fuels such as natural gas and fuel oils. For every unit of electrical energy used on site, roughly three units of primary fuel energy (from coal or natural gas) are required to generate and deliver that electrical energy to the site. Source energy is calculated by applying national, regional, or site-specific multipliers to each form of energy used on site. Regions relying more on hydroelectric, nuclear, and renewable generation have lower site-to-source electricity multipliers. The on-site use of primary fuels can have a small energy multiplier for delivery and upstream (extraction and production) energy requirements. District steam has an additional multiplier associated with distribution losses. Energy costs are reflected more closely by source rather than site energy as electricity pricing includes the cost of primary fuels used in production. Likewise, carbon emissions are reflected better by source than site energy. A more detailed description of site to source energy conversion is provided in the documentation for the Energy Star facility-level benchmarking system ${ }^{2}$. The Energy Star algorithm uses the following national factors to convert from site to source energy:

\footnotetext{
${ }^{2}$ Energy Star Performance Ratings Methodology for Incorporating Source Energy Use (downloaded 5/23/09): http://www.energystar.gov/index.cfm?c=evaluate_performance.bus_benchmark_comm_bldgs
} 
3.34 for electricity, 1.05 for natural gas, 1.01 for fuel oil, 1.01 for diesel fuel, 1.45 for district steam, 1.35 for district hot water, and 1.05 for district chilled water.

While facility- or building-level energy intensity provides a valuable overall metric, the targeting of specific areas for improvement is better served by finer resolution. Hospital energy use can be resolved in various ways. Seasonal trends apparent from utility bills can indicate the importance of external drivers (e.g. cooling related to outdoor air temperature). Time-of-use metering can provide information related to daily and weekly facility schedules. For multi-building campuses, energy use can and should be resolved specifically for the hospital building. Within the hospital, administrators may desire to resolve energy (and costs) by medical department. This may or may not be feasible for some electrical loads (depending on system architecture), and is even more complicated for ventilation and thermal conditioning services.

This benchmarking system is designed to understand energy use through metrics associated with the following major building energy services and systems:

- Cooling (including space and equipment)

- Space heating

- Domestic hot water (DHW)

- Steam

- Ventilation (air movement)

- Lighting

- Miscellaneous equipment and plug loads (including distributed medical equipment and computers).

Additionally considered are the following services and spatial resolutions of specific relevance to hospitals:

- Large (“group 1") medical equipment.

- Patient room areas.

- Other large, resolvable loads (e.g. data centers, kitchens), as feasible.

System-level metrics support energy reduction in several ways. They facilitate identification of systems that are performing poorly in relation to those at other facilities. Information about system performance, components and operational patterns can help identify fundamentally inefficient equipment, inefficient modes of operation, and problems with equipment that lead to inefficient operation. The resolution of total facility energy use into component systems can help prioritize efforts since small improvements to systems that use large amounts of energy may provide more savings than large improvements to systems that use little energy.

\section{Normalizing Factors}

There are two groups of characteristics that impact facility energy use and are outside of the control of facility staff. The first includes location (relevant as climate and weather establish thermal conditioning and lighting constraints); building characteristics such as height, type of construction, orientation, etc.; and basic heating and cooling system configurations. The second group pertains to medical services. Hospital energy use should scale with medical service provision and to a lesser extent capacity. Hospital capacity is indicated primarily by total floor area and the number of licensed beds. The presence and extent of operating rooms, critical care units, high-energy imaging equipment and other energy-intensive services are additional 
measures of capacity. The "product" of patient care can be tracked by various measures including licensed bed-days (inpatient days), admissions (or discharges), and total patient (census) days.

These factors drive overall energy use independent of efficiency, and should thus be considered in comparisons. Factors with simple and direct relations to energy use can be incorporated into the calculated metrics, as noted above for floor area. A second approach is to group facilities by the factors; this is typically done with climate zone. A third approach is to develop regression models that adjust metrics according to the independent characteristics. This is the approach used by EPA's Energy Star facility-level hospital benchmarking system ${ }^{3}$; the rating scale incorporates a multivariate regression model to adjust for both building and activity characteristics.

\section{Special Considerations}

Attribution of both total and resolved energy use in the hospital requires an understanding and accounting for all of the energy flows into the hospital building. This task can be complicated by variations in the configurations of energy using systems and other special factors associated with hospitals. The guidance section provided later in this document addresses some of the questions that will arise when attempting to implement this benchmarking system. This section briefly addresses several issues that may be helpful to consider prior to the presentation of metrics.

Thermal system configurations. Energy use attribution to thermal services (cooling, space heating, domestic hot water, steam) can be challenging owing to the prevalence of central plants that serve other buildings at the facility (e.g., medical office buildings) and variations in the way that heating, hot water and steam systems are combined. If the non-hospital buildings served by a district system are small relative to the hospital (e.g. 15\% or less of the floor area), they can be combined with the hospital for the purposes of thermal system energy assessment. Alternately, energy use at the hospital may be estimated from the thermal energy supplied to the hospital building and the efficiency of the district system used to generate and distribute this thermal energy throughout the facility. The use of waste heat (e.g. to preheat domestic hot water) is a desirable design that can create questions about how to attribute the energy use. This guidance recommends that the energy be attributed to the system to which it is supplied; benefits will appear in the energy intensity measurements for the systems making use of the waste heat.

Spatial resolution. Hospitals contain spaces used for very specialized functions - e.g., surgical suites, intensive care units, medical imaging, etc. - that have varying requirements for lighting, cooling, etc. and highly varying electrical equipment loads. Ideally it would be valuable to assess energy intensity in each area having a designated function. But this is not typically feasible since many of the services, e.g. thermal conditioning and ventilation, are shared across departments. Also, hospital electrical systems are not designed to facilitate monitoring with this level of resolution. However, it is often possible to measure energy use in a defined area or wing of patient rooms. Energy intensity in this sample area can then be extrapolated to determine energy use for all patient room areas. Since patient rooms serve a relatively standard function, there are several metrics related to energy use in patient room areas.

\footnotetext{
${ }^{3}$ http://www.energystar.gov/index.cfm?c=healthcare.bus healthcare benchmark
} 
Temporal resolution and duration of data collection. Energy metrics are generally formulated for annual data to account for seasonal variations and to avoid the potential for unusual events or variations during a shorter monitoring period. This is preferred whenever trend data can be obtained from monitors or sub-meters installed as part of a building automation or energy management system. For hospitals that lack an extensive collection of installed monitors (most existing facilities) data may be obtainable for much shorter periods, e.g. of 1-2 weeks. This is a particular challenge for assessment of heating and cooling energy use which is expected to vary by season and even from day to day depending on weather.

Heating and cooling metrics for short-duration monitoring. The establishment of heating and cooling metrics obtainable with limited duration monitoring requires research and development. The recommendations below require evaluation with data from operating facilities. In all cases, tracking of outdoor air temperature is important to facilitate analysis and identification of opportunities for system improvements. The first recommendation is to measure cooling and heating provision and energy use under varying seasonal weather conditions. Ideally this would include summer and winter for maximum cooling and heating respectively and a neutral season in which outdoor conditions are close to what is desired for indoor comfort (i.e. during Spring or Fall across much of the U.S.). Under neutral "base" conditions, it may be assumed that cooling is being provided primarily to remove heat generated by occupancy and process loads and heating is primarily for re-heat. Base metrics for cooling and heating can be calculated for a one-week duration or as a series of daily values to assess day to day variations.

The second recommendation is to record primary data (e.g. chilled water flow and temperature) at 10-min resolution if feasible and to calculate heating and cooling metrics on an hourly basis. These hourly data can be regressed to outdoor air temperature and the relationship used can be combined with an annual hourly outdoor temperature profile to estimate annual cooling and heating metrics (provision and energy use). The regression likely will need to include hour of day as a second independent variable to account for diurnal variations operation, e.g. to differentiate between a middle-of-the-night hour in the summer and a mid-day hour in the spring which may have the same outdoor temperature but very different internal cooling loads. If this approach is verified through analysis of actual facility data, guidance will be included in future versions of the protocol. Resolved data can be integrated over periods of 1 day or 1 week. Daily values can be calculated along with a value for daily cooling and heating degree-days or degree-hours.

Electric power and energy measurements. The desired metric for AC electric power usage is the real power (the actual power used by equipment), in units of kWh. Measurement of real power requires simultaneous monitoring of current and voltage; which in turn requires physical connection to the electrical conductor (requiring shut-down or special safety procedures) and the use of somewhat less common monitoring equipment. Much more common are measurements of current only; these can be obtained through installation of current transformers (CTs) around (but not connected to) conducting wires. The measured current can be multiplied by the nominal voltage to determine apparent power (power available to the equipment), in units of kVA. Real power and apparent power are related by the power factor, which varies with the type of equipment. The issue is addressed by basing most electrical metrics on the measured apparent power and assuming similar power factors for the same types of equipment in different hospitals. 


\section{Monitoring and Data Collection Challenges}

Determination of thermal energy flow is accomplished by measuring the flow of the thermal fluid (e.g., chilled water or steam) and the temperatures of the fluid supply and return flows (or temperatures entering and leaving the hospital). This is a straightforward process in principle, but requires temperature sensors to be sufficiently precise and accurate (or cross-calibrated) to allow accurate calculation of temperature differences. This is generally not an issue for heating water, but is important for chilled water systems operating on relatively small temperature differences.

\section{Metric Categories \& Rationale}

This section describes rationale for the selected metric categories. Specific metrics are described in the tables that follow.

\section{Thermal Energy and Ventilation Provided to Hospital}

Services: Cooling, heating, domestic hot water, steam, ventilation.

Rationale: Independent of the efficiency with which the loads are being satisfied, these metrics can help identify unusually high service requirements. It is common for hospitals to have excess cooling in the ventilation air provided to some zones which in turn requires reheat of this air. In this situation, both the cooling and heating systems may be efficiently producing and distributing thermal services but the overall system would be wasting energy. Ventilation air supply that greatly exceeds code requirements also represents an opportunity for savings.

\section{System Efficiencies}

Services: Cooling, heating, domestic hot water, ventilation. Rationale: Independent of the loads on the buildings, the systems used to meet these loads can operate with varying efficiency. The highest level metric is the overall system efficiency. The efficiencies of individual equipment components are important, but even efficient components can be combined or utilized in a manner that leads to lower overall efficiency. Heating, domestic hot water (DHW), and steam are considered in varying combinations and configurations to reflect the often inter-connected systems used to produce these services.

\section{Thermal and Ventilation End-Use Intensities (EUI)}

Services: Cooling, heating, domestic hot water, ventilation.

Rationale: This provides information to attribute total energy use at the hospital and thus prioritize efforts to reduce energy use and costs. Even small reductions in the most energy intensive systems may yield greater savings than large improvements in less important systems.

\section{Electrical End-Use Metrics in Hospital}

Services: Lighting, large medical equipment, distributed medical equipment \& plug loads. Rationale: The objective is to identify and quantify major components of the total hospital electrical load. Little is known about the overall electrical load of medical equipment, both large centralized facilities and distributed equipment; this information will guide prioritization of this end use. Patient room areas serve similar functions in most hospitals and are thus suitable for comparison and benchmarking. Determination of end-use intensity and total electrical energy use in patient room areas will provide an estimate of use in diagnostic \& treatment areas. 
Table 1. Metrics for thermal and ventilation services provided to hospital.

\begin{tabular}{|c|c|c|}
\hline Metric & Data required & Comments \\
\hline $\begin{array}{l}\text { Cooling to hospital: } \\
\text { - Annual kBtu/sf-yr } \\
\text { - Base Btu/sf-day } \\
\text { - Hourly kBtu vs. } \\
\text { outdoor temp. }\end{array}$ & $\begin{array}{l}\text { - Supply and return temperatures } \\
(\Delta \mathrm{T}), \text { flow of chilled water to } \\
\text { hospital, outdoor air temperature. }\end{array}$ & $\begin{array}{l}\text { - Annual measure is ideal, but infeasible in many facilities. Other } \\
\text { metrics are proposed and require research validation. } \\
\text { - Base cooling meets occupancy and process loads; measure } \\
\text { during neutral weather conditions. Can be on daily basis. } \\
\text { - Hourly data during peak cooling and neutral weather seasons } \\
\text { may be used to extrapolate to annual estimate. } \\
\text { - If district system, also calculate annual ton-h to multiply by } \\
\text { system efficiency (kWh/ton-h) to get } \mathrm{kWh} / \mathrm{yr} \text { and } \mathrm{kWh} / \mathrm{sf}-\mathrm{yr} \text {. }\end{array}$ \\
\hline $\begin{array}{l}\text { Heating to hospital }{ }^{2} \text { : } \\
\text { - Annual kBtu/sf-yr } \\
\text { - Base Btu/sf-wk } \\
\text { - Hourly kBtu vs. } \\
\text { outdoor temp. }\end{array}$ & $\begin{array}{l}\text { - Supply and return temperatures } \\
(\Delta \mathrm{T}) \text {, flow of heating water to } \\
\text { hospital or supply and return } \\
\text { energy flows of steam. }\end{array}$ & $\begin{array}{l}\text { - Annual measured is ideal, but infeasible in many facilities. Other } \\
\text { metrics are proposed and require research validation. } \\
\text { - Base measured during neutral weather. } \\
\text { - Hourly data during peak heating, cooling and neutral weather } \\
\text { seasons may be used to extrapolate to annual estimate. } \\
\text { - Reheat may increase during peak cooling season. }\end{array}$ \\
\hline $\begin{array}{l}\text { Domestic hot water } \\
\text { (DHW) to hospital: } \\
\text { - kBtu/sf-yr }\end{array}$ & $\begin{array}{l}\text { - Supply and return temperatures } \\
(\Delta \mathrm{T}), \text { flow of hot water to } \\
\text { hospital. }\end{array}$ & $\begin{array}{l}\text { - Applicable to central systems only. } \\
\text { - Weekly measure can be extrapolated to annual load. } \\
\text { - May need to consider variable hospital occupancy / census. }\end{array}$ \\
\hline $\begin{array}{l}\text { Actual vs. required air } \\
\text { flow by zone. } \\
\text { - cfm / cfm }\end{array}$ & $\begin{array}{l}\text { - Actual airflow by zone. } \\
\text { - Code required airflow by zone. }\end{array}$ & $\begin{array}{l}\text { - Airflow impacts energy use for ventilation, cooling and heating. } \\
\text { - Screen to see if supply is greatly in excess of requirements. }\end{array}$ \\
\hline
\end{tabular}

${ }^{1}$ Convert to ton-h/sf-yr to combine with system kW/ton (see Table 2) to calculate site kWh/sf-yr.

${ }^{2}$ Note that equipment to measure steam energy flows is not generally in place or readily installed. 
Table 2. Thermal and ventilation system efficiencies

\begin{tabular}{|c|c|c|}
\hline Metric & Data required & Comments \\
\hline $\begin{array}{l}\text { Cooling system overall } \\
\text { efficiency: } \\
\text { - Site } \mathrm{kW} / \text { ton }\end{array}$ & $\begin{array}{l}\text { - Power/energy to create, distribute } \\
\text { cooling (chillers, pumps, etc.) } \\
\text { - Cooling supplied by central } \\
\text { plant, from chilled water supply } \\
\text { and return temp }(\Delta \mathrm{T}) \text { and flow. }\end{array}$ & $\begin{array}{l}\text { - Energy units are } \mathrm{kWh} / \mathrm{ton}-\mathrm{h} \text {. } \\
\text { - Can require a large number of power measurements. } \\
\text { - Integrated performance, e.g. over } 1 \text { week of cooling season. } \\
\text { - Analyze relative to cooling produced and/or wet bulb temp. }\end{array}$ \\
\hline $\begin{array}{l}\text { Heating \& DHW system } \\
\text { efficiencies: } \\
\text { - Source kBtu / } \\
\text { kBtu to hospital }\end{array}$ & $\begin{array}{l}\text { - Net fluid energy flows (supply- } \\
\text { return) from central plant. } \\
\text { - Fuel energy supplied to boilers. } \\
\text { - Electricity for large pumps. }\end{array}$ & $\begin{array}{l}\text { - Applicable to systems serving hospital only or other buildings. } \\
\text { - Ignore small electrical loads. Monitor for one week or more. } \\
\text { - This combined metric recognizes that central DHW systems } \\
\text { often connected to heating; resolve as feasible. } \\
\text { - Steam systems may combine process steam, humidification, } \\
\text { heating and DHW in various combinations; resolve to } \\
\text { component systems as feasible or forego this metric. }^{3}\end{array}$ \\
\hline $\begin{array}{l}\text { Boiler efficiencies: } \\
\text { - kBtu out / kBtu in }\end{array}$ & $\begin{array}{l}\text { - Net energy flows (supply-return) } \\
\text { from central plant. } \\
\text { - Fuel energy input to boiler. }\end{array}$ & $\begin{array}{l}\text { - Integrated over operating week. } \\
\text { - Consider steam and water boilers separately. } \\
\text { - Benefit of DHW pre-heat captured in DHW efficiency metrics. }\end{array}$ \\
\hline $\begin{array}{l}\text { Ventilation efficiency: } \\
\text { - Base W/cfm } \\
\text { - Peak W/cfm }\end{array}$ & $\begin{array}{l}\text { Airflow (kcfm), power }(\mathrm{kW}) \text { for } \\
\text { each fan and total for each group } \\
\text { of fans: supply, return, exhaust. }\end{array}$ & $\begin{array}{l}\text { - Base satisfies air change requirements and removal of internally- } \\
\text { generated heat; peak includes seasonal cooling. } \\
\text { - Obtain flow from fan rating or past balance report. } \\
\text { - Actual W for supply will vary with filter loading. }\end{array}$ \\
\hline
\end{tabular}

${ }^{1}$ Source energy accounts for efficiency of electricity generation from primary fuel, losses in distribution system for all fuels, etc.; this is best metric for comparing different forms of energy used on site.

${ }^{2}$ Includes all substantial energy loads for generation (e.g. boiler fuel) and distribution (e.g. heating water pumps) of thermal service. This metric is combined with actual quantity of service provided to hospital (Table 1) to calculate energy use intensity (source kBtu/sf-yr) for hospital building.

${ }^{3}$ Note that equipment to measure steam energy flows is not generally in place or readily installed. 
Table 3. Metrics for hospital thermal and ventilation energy intensities.

\begin{tabular}{|c|c|c|}
\hline Metric $^{1,2}$ & Data required & Comments \\
\hline $\begin{array}{l}\text { Cooling EUI: } \\
\text { - Site kWh/sf-yr } \\
\text { - Source kBtu/sf-yr } \\
\text { - T-varying Wh/sf-h }\end{array}$ & $\begin{array}{l}\text { - Cooling system efficiency and } \\
\text { cooling supplied to hospital, or } \\
\text { - Total power of all cooling } \\
\text { equipment (hospital only). }\end{array}$ & $\begin{array}{l}\text { - Attribute part of total facility (central plant) cooling energy to } \\
\text { hospital; based on fraction of total cooling load to hospital. } \\
\text { - Also track outdoor temperature. } \\
\text { - Extrapolation techniques under development. }\end{array}$ \\
\hline $\begin{array}{l}\text { Heating EUI: } \\
\text { - Source kBtu/sf-yr } \\
\text { - T-varying Btu/sf-h }{ }^{3}\end{array}$ & $\begin{array}{l}\text { - Heating system efficiency and } \\
\text { heating supplied to hospital, or } \\
\text { - Total energy of all heating } \\
\text { equipment (hospital only). }\end{array}$ & $\begin{array}{l}\text { - If system just serves hospital, need only fuel energy to boilers } \\
\text { and electricity to large pumps. } \\
\text { - Also track outdoor temperature. } \\
\text { - Extrapolation techniques under development. }\end{array}$ \\
\hline $\begin{array}{l}\text { DHW EUI: } \\
\text { - Source kBtu/sf-yr }\end{array}$ & $\begin{array}{l}\text { - DHW system efficiency. } \\
\text { - DHW to hospital. }\end{array}$ & $\begin{array}{l}\text { - If system just serves hospital, need only fuel energy to boilers } \\
\text { and electricity to large pumps. Extrapolate from week to year. }\end{array}$ \\
\hline $\begin{array}{l}\text { Steam EUI: } \\
\text { - Source kBtu/sf-yr }\end{array}$ & - Fuel energy to steam boilers. & $\begin{array}{l}\text { - Applicable when steam system only serves hospital. } \\
\text { - Assumes pump \& boiler fan energy small relative to boiler fuel. } \\
\text { - Measure } 1 \text { week or more, extrapolate to year. }\end{array}$ \\
\hline $\begin{array}{l}\text { Heating }+ \text { Steam }+ \text { DHW } \\
\text { EUI: } \\
\text { - Source kBtu/sf-yr } \\
\text { - T-varying Btu/sf-h }{ }^{3}\end{array}$ & $\begin{array}{l}\text { - Refer to data requirements for } \\
\text { individual services above. }\end{array}$ & $\begin{array}{l}\text { - Broadest metric for combined systems, can also calculate for } \\
\text { pairs (e.g., Steam + DHW). } \\
\text { - For any system serving hospital only, need only fuel energy to } \\
\text { boilers and electricity to large pumps. }\end{array}$ \\
\hline $\begin{array}{l}\text { Ventilation EUI: } \\
\text { - Site kWh/sf-yr } \\
\text { - Source kBtu/sf-yr }\end{array}$ & $\begin{array}{l}\text { - Total electric energy for all fans } \\
\text { (supply, return, exhaust). }\end{array}$ & $\begin{array}{l}\text { - Number of measurements may be large but acquisition should be } \\
\text { straightforward. }\end{array}$ \\
\hline
\end{tabular}

- Source kBtu/sf-yr

Source energy accounts for efficiency of electricity generation from primary fuel, losses in distribution system for all fuels, etc.; this is best metric for comparing different forms of energy used on site. Source energy provides meaningful approach to combine electrical (pumps) and other fuels (boilers) used in generation and distribution of heating, hot water, etc.

2 Metrics can alternately be normalized to \# of patients served by hospital (e.g., patient days) per year.

${ }^{3}$ See notes in Table 1 and "Special considerations" about hourly data to assess variability with weather and extrapolation 
Table 4. Electrical end use metrics.

\begin{tabular}{|c|c|c|}
\hline \multicolumn{3}{|c|}{ ELECTRICAL END USE METRICS } \\
\hline Metric $^{1,2}$ & Data required & Comments \\
\hline $\begin{array}{l}\text { Non-equipment electric } \\
\text { EUI of hospital: } \\
\text { - Site kWh/sf-yr }\end{array}$ & $\begin{array}{l}\text { - Total of Normal, Critical, \& Life } \\
\text { Safety branches for hospital. } \\
\text { - Subtract power to large HVAC } \\
\text { equipment on these branches. }\end{array}$ & $\begin{array}{l}\text { - Composite of lighting, medical equipment and plug loads; valid } \\
\text { for comparisons among hospitals. } \\
\text { - Costly to install temporary monitors on high voltage, high } \\
\text { current distribution panels; likely limited to existing monitors. }\end{array}$ \\
\hline $\begin{array}{l}\text { Electrical EUI of patient } \\
\text { room area: } \\
\text { - Site } \mathrm{kWh} / \mathrm{sf}-\mathrm{wk}\end{array}$ & $\begin{array}{l}\text { - Total of Normal \& Critical } \\
\text { branches for sample area. } \\
\text { - Sample area floor space (sf) and } \\
\text { patient census or number of beds. }\end{array}$ & $\begin{array}{l}\text { - Composite of lighting, medical equipment and plug loads. } \\
\text { - Patient bed areas serve similar function across hospitals; relevant } \\
\text { for comparisons \& benchmarking. } \\
\text { - Extrapolate to all patient bed areas of hospital. }\end{array}$ \\
\hline $\begin{array}{l}\text { Non-equipment electrical } \\
\text { EUI of D\&T areas: } \\
\text { - Site kWh/sf-wk }\end{array}$ & $\begin{array}{l}\text { Total NL + CR for patient room } \\
\text { areas (calculate from sample). } \\
\text { - Total non-equipment electric } \\
\text { energy to hospital (above). }\end{array}$ & $\begin{array}{l}\text { Composite of lighting, medical equipment and plug loads in } \\
\text { diagnostic \& treatment areas; valid for comparisons among } \\
\text { hospitals. }\end{array}$ \\
\hline $\begin{array}{l}\text { Lighting power load of } \\
\text { patient room area, } \\
\text { - Installed W/sf }\end{array}$ & $\begin{array}{l}\text { - Census of lighting in sample of } \\
\text { patient bed area (installed W). }\end{array}$ & $\begin{array}{l}\text { - Group for purpose of estimating overall energy use by } \\
\text { combining schedule and installed capacity. } \\
\text { - Independently useful metric for comparison. }\end{array}$ \\
\hline $\begin{array}{l}\text { Lighting EUI of patient } \\
\text { room area: } \\
\text { - Site } \mathrm{kWh} / \mathrm{sf} \text {-wk }\end{array}$ & $\begin{array}{l}\text { - Installed W/sf and schedule of } \\
\text { operation for light sources, OR } \\
\text { - Power supplied to lighting. }\end{array}$ & $\begin{array}{l}\text { - Provides estimate of lighting energy and other plug loads when } \\
\text { subtracted from total power in patient room area. } \\
\text { - Monitor directly when lighting on discrete panels. }\end{array}$ \\
\hline $\begin{array}{l}\text { Illumination in patient } \\
\text { room area: } \mathrm{fc}^{3}\end{array}$ & $\begin{array}{l}\text { - Illuminance at designated } \\
\text { locations (TBD) }\end{array}$ & $\begin{array}{l}\text { - Measure actual illuminance in patient rooms, hallways, etc. } \\
\text { - Identify over-design of lighting }\end{array}$ \\
\hline $\begin{array}{l}\text { Medical equipment, plug } \\
\text { loads of patient room } \\
\text { areas: Site } \mathrm{kWh} / \mathrm{sf}-\mathrm{wk}\end{array}$ & $\begin{array}{l}\text { - Subtract lighting EUI from total } \\
\text { electrical EUI of patient room } \\
\text { areas. }\end{array}$ & $\begin{array}{l}\text { - Currently little is known about loads of medical equipment and } \\
\text { other plug loads. }\end{array}$ \\
\hline $\begin{array}{l}\text { Energy intensity of large } \\
\text { medical equipment: } \\
\text { - Site } \mathrm{kWh} / \mathrm{yr} \\
\text { - Site } \mathrm{kWh} / \mathrm{unit} \text { activity }\end{array}$ & $\begin{array}{l}\text { - Power for each separable facility } \\
\text { or large medical equipment. } \\
\text { - Equipment-specific activity } \\
\text { metric (patient, scan, etc.) }\end{array}$ & $\begin{array}{l}\text { - Info needed on actual energy use of this equipment } \\
\text { - Need to identify relevant activity measures, e.g. number of } \\
\text { patients served by equipment. }\end{array}$ \\
\hline
\end{tabular}


Table 5. Other metrics for energy efficiency evaluation (PARTIAL LIST) ${ }^{\mathbf{1}}$

\section{OTHER METRICS}

\begin{tabular}{|l|}
\hline Metric \\
\hline Temperature set points
\end{tabular}

\section{Data required}

- Temperature set point ranges in locations throughout facility

RH set points

- RH set point ranges in locations throughout facility

\section{Comments}

- Tight temperature range demands more conditioning

- Tight temperature range demands more conditioning

${ }^{1}$ This table is a placeholder for any other metrics or data that may inform opportunities for energy savings and efficiency gains. 


\section{Implementation Protocol}

The following are the major steps for implementing the hospital energy benchmarking system. This is intended to guide implementation by practitioners familiar with hospital mechanical and electrical systems and experienced in the installation of monitoring equipment.

0. Benchmark facility using EPA Energy Star Portfolio Manager.

1. Identify flows and boundaries of major energy-using systems

a. Identify thermal energy flows (cooling, space heating, domestic hot water, steam)

b. Review electrical system organization and special features

c. Consider temporal and seasonal variance of energy-using systems

2. Identify target metrics and data

a. Identify component data needed for each metric

b. Determine data already being monitored

c. Consider options for obtaining other data

i. Install permanent monitors for direct measurement

ii. Shorter term monitoring

iii. Surrogate measures (time of use, etc.)

3. Develop monitoring and data collection plan

a. $\operatorname{Re}(-\mathrm{set})$ trending of existing data streams

b. Calibration of existing sensors

c. Installation of new permanent sensors

d. Sensors installed for temporary monitoring

e. One-time measurements (e.g. fixed-speed pump or fan power)

f. Data collection materials and implementation schedule

4. Implement monitoring plan; collect data

5. Obtain information on facility characteristics

a. Total floor area of hospital and other buildings to be included in EUI calculations

b. Patient census

c. Floor space of patient room areas (sampled area and total)

6. Data processing and analysis

a. Review monitoring results for quality assurance

b. Construct consolidated database

c. Calculate metrics with time-resolved data

d. Calculate time-integrated metrics

e. Data analysis

7. Compare metrics to benchmarks and assess opportunities to reduce energy consumption

\section{Implementation Guidance}

The following draft guidance is intended to address critical questions and key considerations that will arise when implementing the energy benchmarking system. The notes are organized by the major steps listed in the outline above. The intent is to update this guidance based on lessons learned during implementation.

Step 0. Benchmark facility using EPA's Energy Star Portfolio Manager 
The objective of this step is to obtain a facility-level energy benchmarking score using EPA's Energy Star for Healthcare system. Detailed guidance is provided at the Energy Star web site. ${ }^{4}$

\section{Step 1. Identify flows and boundaries of major energy-using systems}

The objective of this step is to review the major energy using systems to understand and identify the points at which energy enters the hospital building(s).

\section{1a. Identify thermal energy flows (cooling, heating, domestic hot water, steam)}

For each service, determine the appropriate boundaries for energy monitoring. The key question is whether the service is provided in a district system, in which a central plant serves buildings other than the hospital, or if the plant is dedicated either exclusively or primarily to the hospital. If other buildings are served, decide if they can be considered together with the hospital for the purpose of benchmarking the service. As a general rule, other buildings should be included if their combined floor space is about $15 \%$ or less of the hospital floor space. Note that the floor space used for a thermal service is the entire floor space served. For example, heating may be supplied only to exterior spaces; but the area used in calculating heating end use intensity should include the interior areas. Note also that different floor space denominators may be used for different services, e.g. if cooling is shared with a small office building whereas heating is provided only to the hospital building.

For district systems serving other buildings of substantial size, the recommended approach is to assess the following two quantities: thermal service provided to the hospital and overall efficiency of the system to provide and distribute the service. With these quantities, the energy used to provide the service to the hospital can be estimated by calculation. Energy used to distribute the service through the hospital should be excluded from the denominator in the system efficiency calculation but added to the EUI of the service at the hospital. The total end use intensity (EUI) for providing this service to the hospital is thus calculated as follows: central (district) system efficiency (Btu distributed / Btu to produce and distribute) * amount of service used by hospital building (Btu) + energy to distribute service within hospital (Btu of electrical energy used by pumps distributing service through hospital). Since the majority of cooling systems operate exclusively on electric power, the EUI can be calculated in terms of site energy and converted later to source energy as needed.

Alternately, some fraction of the total amount of energy used to produce and distribute the service can be attributed to the hospital using an estimation technique, e.g. by considering the breakdown of floor space among the buildings. If this approach is used, the hospital floor space should be weighted more than that of other buildings owing to the generally higher demand on thermal services. This approach should be used with caution.

Consider inter-connections among the heating, DHW and steam systems and determine whether it is feasible to obtain metric values for each service distinctly of for which combinations of services.

\footnotetext{
${ }^{4}$ http://www.energystar.gov/index.cfm?c=healthcare.bus healthcare
} 
Another issue with assessment of energy for thermal services is the lack of existing sub-metering for natural gas. It is worthwhile to consider at this stage how facility level natural gas use may be apportioned if there are multiple systems each using substantial amounts of gas. Options include installation of meters for specific pieces or banks of equipment (e.g. during equipment shutdown or rotations) and inferring natural gas use through time of use or other estimation methods.

\section{1b. Review electrical system organization and special features}

The objective of this step is to understand the electrical system in preparation for targeting equipment and locations for power measurements. The specific tasks include the following:

a. Assess feasibility (locations and number of sampling points required) to measure power on each electrical branch (critical, equipment, normal, life safety) going into hospital.

b. Identify large medical equipment / facilities for separate monitoring.

c. Identify large HVAC equipment not on equipment branch.

d. Identify / select sample patient room area(s).

The preferred approach for large medical equipment (e.g., MRI, other imaging) is to monitor each piece of equipment separately and obtain information about the activity of the equipment over the same time period (e.g., in terms of patients served or scans performed). The specific activity metric will vary by equipment.

The purpose of identifying large medical equipment that is not on equipment branch is for accurate assessment of the amount of electrical energy used for non-HVAC applications.

Patient room sample area(s) should be selected to represent all patient room areas in the hospital. Multiple areas may be monitored as needed to capture variability in functional or operational characteristics (e.g., presence in building wings of varying construction, varying levels of medical attention, etc.).

\section{1c. Consider temporal and seasonal variance of energy-using systems}

For some systems energy use may be roughly constant (e.g., constant volume ventilation; lighting in patient areas). In most systems, energy use varies throughout each day and can differ on weekends vs. weekdays. Some services and systems, such as cooling, vary seasonally. These temporal variations should be considered when selecting monitoring periods and durations.

\section{Step 2. Identify metrics to be obtained}

The objective of this step is to identify the metrics that will be targeted during the energy monitoring and measurement stage.

\section{2a. Select target data points for energy monitoring}

Using as a guide the tables above, select the data points that are suitable and accessible. This first level of screening should be the level of technically feasible with common monitoring equipment. Constraints including installation costs, availability of monitoring equipment, and prioritization of desired metrics will often lead to a reduction in the number of points that are monitored. When selecting monitoring points for electric power, consider "upstream" measurement points to capture redundant equipment, e.g., single variable frequency drive (VFD) 
controller for redundant heating water pumps. Measurements of electrical energy used in thermal systems should include all large distribution pumps; smaller equipment such as feed water pumps and boiler fans can be estimated if they comprise a small contribution to total energy use for the system.

\section{2b. Determine data already being monitored}

Review the available building automation (BAS), energy management (EMS) or other system and any other installed measurement devices to determine which of the target data points are already being monitored. Some data points may be measured with installed equipment but not "trended" or recorded by the BAS/EMS. The expectation is that most facilities constructed in the past decade will have installed measurement equipment that can provide data for at least some of the desired points, but these points typically will not be sufficient to facilitate acquisition of the majority of desired data. In addition to monitors connected to the automated system, note that many VFD controllers provide instantaneous power information via built-in displays; these can be used to estimate composite and cumulative fan energy. Recent or past balancing reports can provide information to assist in estimation of ventilation-related metrics.

\section{2c. Identify equipment needed for monitoring of additional points}

Measurement equipment availability will often represent a major barrier to energy monitoring. The expectation is that this benchmarking system will be implemented by outside groups working with the hospital staff; the outside groups may include researchers, energy auditing and consulting firms, retro-commissioning professionals, and other similarly trained professionals. These groups should have access to monitoring equipment, but the stock may be insufficient to measure all technically feasible points in a single period. Lists of required and available equipment will be helpful in developing a monitoring plan.

\section{Step 3. Develop monitoring plan}

The objective of this step is to develop a plan covering key phases of implementation, as outlined below.

\section{3a. $\operatorname{Re}(-$-set) trending for existing data streams}

The addition of points to the stream of trended or stored data could raise concerns about overloading the capacity of older systems. This issue can be addressed by removing less valuable points or reducing the frequency at which some other points are stored. For most data points of interest to energy benchmarking, temporal resolution (data storage) of $10 \mathrm{~min}$ is sufficient.

\section{3b. Calibrations of existing sensors}

The accuracy of installed sensors should not be assumed. The first quality assurance check is to view recent and real time data being reported for all sensors and assess whether the reported values are reasonable. The most rigorous check involves calibration of the sensors using an independently verifiable or "primary" source. Ad hoc checks are possible and often sufficient. For example, a temperature sensor can be placed under the insulation of a thermal system pipe (e.g. heating water) to independently measure the temperature of the fluid. Consistency between temperature sensors is very important for the cooling system (supply and return flows) as it operates on a relatively small temperature difference. The heating and hot water systems are not as sensitive owing to larger temperature differences between supply and return flows. The 
generally preferred approach is to install a pre-calibrated sensor in parallel to an existing sensor and collect data as the system progresses through a normal operation. At the completion of monitoring, the permanently installed sensor can be calibrated against the temporary monitor.

\section{3c. Installation of new permanent sensors}

The process of reviewing available information and planning for benchmarking may suggest opportunities for installation of additional permanent sensors to facilitate energy monitoring. Equipment and installation costs vary by monitoring device, but some - including temperature sensors - are inexpensive and may be easy to install (e.g. if wells are available but not being used). Generic guidance for commercial building energy monitoring equipment is relevant to hospital systems and should be consulted.

\section{3d. Sensors installed for temporary monitoring}

The installation of temporary monitoring equipment must be planned around staff and equipment availability. Specifications for required equipment should be assessed at this planning stage. All equipment should be installed by trained and experienced professionals working together in coordination with the hospital staff.

\section{3e. One-time measurements}

Equipment that operates in a fixed or consistent manner - e.g. fixed speed pumps and exhaust fans - can be measured once to determine power use during operation, then monitored to track operation with equipment that is less costly and easier to install. Constant volume air handling units would ideally have airflow measurements conducted as part of the benchmarking exercise. A more practical approach is to use values from the most recent balancing report.

\section{3f. Data collection materials and implementation schedule}

Considering temporal variability of each metric and the guidance provided in the tables above, select the appropriate duration for monitoring each point. Seasonal variations should also be considered. In recognition of equipment limitations, consider a staged implementation in which data streams are monitored in groups over two or more weeks. Heating, cooling and ventilation should be monitored together. Non-HVAC electric loads should also be monitored together if at all feasible to allow same-period calculations relating the patient room and large medical equipment EUIs to total non-HVAC electrical EUIs. Existing meters and sub-meters should be set to automatically record data at a level of meaningful time resolution, e.g. $10 \mathrm{~min}$. If automatic recording is not available, reading of installed gas and/or electric meters should ideally occur at the same time each day and at a time of low use (e.g. late night) to reduce the influence of small variations in the reading time. If water and/or steam boilers are powered by natural gas and energy use is being estimated by run time, the run time values should be recorded at the same time as the natural gas meter readings. If VFD controllers display power, the readings should be recorded as a check on other power measurements for these devices.

${ }^{5}$ Gillespie, K.L., Haves, P., Hitchcock, R.J., Deringer, J.J. and Kinney, K., 2007. A Specifications Guide for Performance Monitoring Systems, Lawrence Berkeley National Laboratory (Berkeley, CA), Pacific Gas and Electric Company (San Ramon, CA), Deringer Group (Berkeley, CA), QuEST (Berkeley, CA), March 23, 2007. http://cbs.lbl.gov/performance-monitoring/specifications/ 


\section{Step 4. Implement monitoring plan; collect data.}

The objective of this step is self-explanatory: to obtain the information needed to calculate metrics of energy performance. For permanently installed monitoring equipment, the BAS/EMS can be set-up to provide data and/or calculate metrics on an ongoing basis.

\section{Step 5. Obtain information on facility characteristics}

The objective of this step is self-explanatory: to obtain information about the facility that is required for calculation of energy performance metrics.

\section{5a. Total floor area of hospital and other buildings to be included in EUI calculations}

As noted above, different floor areas may be used to calculate energy metrics for different systems (e.g. if cooling serves hospital plus another building while heating serves hospital only).

\section{5b. Patient census}

The patient census should be obtained for all monitoring periods and preferably also on an annual basis to assess how the monitored periods relate to the annual record. In addition to the patient census for the entire hospital, patient counts ideally should be obtained for all areas of patient rooms monitored.

\section{5c. Floor area of patient room areas (sampled area and total)}

This information is required to extrapolate from the sample patient area(s) monitored for energy performance to all patient room areas in the hospital. The intent is to estimate how much of the total non-equipment electrical energy is used in patient room areas. The remainder can be attributed to diagnostic \& treatment and hospital common areas.

\section{Step 6. Data processing and analysis}

The objective of this step is to use the collected data to calculate energy performance metrics that will be used for benchmarking.

\section{6a. Review monitoring results for quality assurance}

The key caution here is not to assume that all collected and compiled data is correct. As suggested above for permanently installed monitoring equipment, the first check is to assess the basic plausibility of the data. Formal quality assurance procedures can be used to systematically assess data quality. Additional guidance may be provided in subsequent protocol versions

\section{6b. Construct consolidated database}

Combine trend data from the BAS/EMS with data collected from supplemental monitoring. Incorporate outdoor air temperature and humidity, one-time measurements of power usage for fixed operation equipment, and normalizing values for floor area and patient census.

\section{6c. Calculate metrics with time-resolved data}

Metrics should be calculated at the greatest time resolution available and these results should be archived for later review. For example, if chilled water temperatures and flows are measured on a 10-min basis, the kBtu of cooling provided to the hospital should first be calculated with this resolution. Also calculate fixed speed equipment power use during each time interval. Combine 
interim values as needed to calculate each metric; for example, calculate power for all cooling equipment in each interval. Most of the metrics listed in the tables above are calculated directly from measured or estimated energy and associated normalization factors (e.g. square feet of floor space). Time-resolved data can assist in identifying periods of inefficient or simply high-load operation.

\section{6d. Calculate time-integrated metrics}

The time-resolved metrics calculated above can be integrated over periods required for analysis or benchmarking (e.g. over one week). As noted in tables, air flow for individual fans and system wide can be from installed monitors or from previous balancing reports if current measurements are not available. Some integrated metrics such as annual cooling and heating provision and energy use require extrapolation. There are approaches that have been used by LBNL researchers (and presumably others in the field) that need to be evaluated for their applicability to hospitals. One proposed approach is to use regress hourly cooling and heating metrics against outdoor air temperature and time of day (or another indicator of facility operating schedule). This approach requires data covering as much as possible of the annual range of outdoor temperatures, i.e. data from both peak cooling and peak heating times. Data from just the peak cooling period may be sufficient to develop a relationship for cooling provision and energy that can be used to extrapolate to annual cooling provision and energy use.

Calculate an initial estimate of the integrated energy use for natural gas and fuel oil boilers. Resolve individual equipment estimates against total natural gas and/or fuel oil use.

\section{6e. Data analysis}

Time-resolved and integrated data can be analyzed to improve understanding of system operation and to identify efficiency opportunities. The intent is to provide guidance on specific analyses in future versions of this guidance document.

\section{Step 7. Compare metrics to benchmarks and assess opportunities}

The objective of this step is to use the information obtained through the process described above to assess opportunities and to prioritize focus areas for energy efficiency improvements. Guidance on this task is a high priority for further development. 


\section{Types and Locations of Measurements}

This section lists the types and locations of data to be monitored or otherwise obtained for the calculation of the energy performance metrics provided above. This list is intended to facilitate planning and assessment of monitoring equipment needs.

Electrical data points

- Central plant equipment resolved by system (note: if possible to measure total electrical power to central plant, may be able to measure only subset of following and estimate the remainder by difference):

- Equipment not related to cooling (may be able to get cooling by subtraction)

- Primary heating water pumps

- Secondary heating water pumps, if present

- AHUs for cooling, heating rooms of central plant

- Boiler fans

- Condensate return pumps if in central plant (often distributed)

- Steam boiler feed water pumps (varies)

$\circ$ Cooling equipment

- Chillers

- Primary chilled water pumps

- Secondary chilled water pumps

- Evaporator pumps

- Cooling tower fans

- Air handling units (AHU) (1-2/ea per AHU; 5-15 AHUs)

- Critical and Normal for selected patient room areas (2 per sampled area)

- Large medical equipment / facilities (1 per facility)

- Large HVAC equipment on CR or NL (not EQ) branches (varies)

Electrical distribution and feeds, as feasible from installed sub-meters

- Main feed of each branch into hospital building

- Central plant main feeds (MCC, equipment branch only, other)

Water flow data points

- Cooling water in/out of hospital building

- Cooling water supply/return from central plant (if multiple buildings served)

- Heating water in/out of hospital building

- Heating water in/out of central plant (if multiple buildings served)

- Domestic hot water into hospital building

- Domestic hot water out of hospital building

Water temperature data points

- Cooling water in/out of hospital building

- Cooling water supply/return from central plant (if multiple buildings served)

- Hot water in/out of hospital building

- Heating water in/out of central plant (if multiple buildings served)

- Domestic hot water into hospital building 
- Domestic hot water out of hospital building

Other data points

- Total plan natural gas and fuel oil use

- Fuel use for each boiler (or firing rate and fun time)

- Steam energy flows in/out of hospital building

- Airflow for each AHU supply and return (many)

- Airflow for each exhaust fan (many)

Equipment characteristics

- Cooling system type, rated efficiencies, operational patterns

- Heating system type, rated efficiencies, operational patterns

- Ventilation system type

- Design and previously measured airflows

- Operational patterns

- Hot water system type, rated efficiency

- Lighting equipment in selected patient room areas

Facility characteristics

- Configuration of heating and cooling systems: where/how generated, buildings served?

- Total floor area of all buildings served by central cooling, heating systems

- Total floor area of hospital building

- Total floor area of patient room area

- Total floor area of D\&T areas

- Floor areas sampled (for electrical use) in patient room areas

- Patient census days (includes admission but not discharge day)

- Admissions + Outpatient visits as metric of total D\&T activity?

Large Medical Equipment

- $\quad$ List of equipment \& electrical branches

- Activity logs (e.g. number of patients, number of scans, etc.)

Normalization and other factors

- Total floor area of all buildings served by central cooling, heating systems

- Total floor area of hospital building

- Floor areas sampled (for electrical use) in patient room areas

- Total floor area of patient room area

- Total floor area of D\&T areas

- Patient census days (includes admission but not discharge day)

- Admissions + Outpatient visits as metric of total D\&T activity? 


\section{Benchmarks}

Draft benchmarks are available for only some of the performance metrics identified above.

Most of the draft benchmarks are based on hospital energy end use estimates presented on LBNL's EnergyIQ commercial building benchmarking web site ${ }^{6}$; these estimates were obtained from simulation modeling of the CEUS building dataset by Itron, Inc. ${ }^{7}$ Benchmarks are presented for consolidated "coastal" and "inland" climates and for the mountain climate region. The Coastal group includes CEUS data for 22 hospitals in "North Coast", "Central Coast" and "South Coast" regions. The Inland group includes 53 hospitals in "Central Valley", "Desert" and "South Inland" regions. The "Mountain" region includes 4 data points. The CEUS distributions for all available metrics - including cooling site energy, cooling source energy, heating source energy, domestic hot water source energy and ventilation site energy - are provided in a series of figures following the tables of draft benchmarks. There is a clear difference in the distributions between coastal and inland areas for cooling, and for heating there is a clearly different modality. Since there are not such clear differences in the distributions for service (domestic) water heating and ventilation, the draft benchmarks for these metrics are derived from the statewide sample. Draft benchmarks for patient room area lighting energy are taken from CEUS statewide end-use estimates for nursing homes. It is important to note that since the CEUS end-use estimates are based on commercial building energy simulations that were not tailored in great detail to each facility they should be considered as highly uncertain. Benchmarks may need to be resolved as a database of measured data and more careful estimates are developed.

The unavailability of data or estimates for many metrics reflects the fact that they have not been used (commonly or perhaps not at all) in previous hospital energy assessment efforts. Draft benchmarks for some of these metrics may be developed by engineering analysis and/or expert knowledge as the benchmarking system is further developed.

Provided below is a table of draft benchmarks for selected metrics and a second table of metrics for which draft benchmarks are needed.

\footnotetext{
${ }^{6}$ http://energyiq.lbl.gov/benchmark.html

7 http://www.energy.ca.gov/ceus/index.html
} 
Table 6. Draft energy benchmarks for California hospitals.

\begin{tabular}{|c|c|c|c|}
\hline Metric & Region & Benchmarks ${ }^{1}$ & Source \& notes \\
\hline \multicolumn{4}{|c|}{ HOSPITAL BUILDING ENERGY USE INTENSITIES (EUI) } \\
\hline $\begin{array}{l}\text { Cooling EUI of hospital, } \\
\text { site } \mathrm{kWh} / \mathrm{sf}-\mathrm{yr} \text {, }\end{array}$ & CA coastal & $\begin{array}{l}\text { Typical: } 4.5 \\
\text { Target: } 3.6\end{array}$ & $\begin{array}{l}\text { Based on } 22 \text { hospitals in CEUS } \\
\text { coastal areas. }\end{array}$ \\
\hline $\begin{array}{l}\text { Cooling EUI of hospital, } \\
\text { site } \mathrm{kWh} / \mathrm{sf}-\mathrm{yr} \text {, }\end{array}$ & CA inland & $\begin{array}{l}\text { Typical: } 6.6 \\
\text { Target: } 5.0\end{array}$ & $\begin{array}{l}\text { Based on } 53 \text { hospitals in CEUS, CA } \\
\text { inland areas. }\end{array}$ \\
\hline $\begin{array}{l}\text { Cooling EUI of hospital, } \\
\text { source kBtu/sf-yr }\end{array}$ & CA coastal & $\begin{array}{l}\text { Typical: } 44 \\
\text { Target: } 36\end{array}$ & $\begin{array}{l}\text { Based on } 22 \text { hospitals in CEUS, CA } \\
\text { coastal areas. }\end{array}$ \\
\hline $\begin{array}{l}\text { Cooling EUI of hospital, } \\
\text { source kBtu/sf-yr }\end{array}$ & CA inland & $\begin{array}{l}\text { Typical: } 65 \\
\text { Target: } 50\end{array}$ & $\begin{array}{l}\text { Based on } 53 \text { hospitals in CEUS, CA } \\
\text { inland areas. }\end{array}$ \\
\hline $\begin{array}{l}\text { Heating EUI of hospital, } \\
\text { source kBtu/sf-yr }\end{array}$ & CA coastal & $\begin{array}{l}\text { Typical: } 96 \\
\text { Target: } 30\end{array}$ & $\begin{array}{l}\text { Based on } 22 \text { hospitals in CEUS, CA } \\
\text { coastal areas. }\end{array}$ \\
\hline $\begin{array}{l}\text { Heating EUI of hospital, } \\
\text { source kBtu/sf-yr }\end{array}$ & CA inland & $\begin{array}{l}\text { Typical: } 81 \\
\text { Target: } 10\end{array}$ & $\begin{array}{l}\text { Based on } 53 \text { hospitals in CEUS, CA } \\
\text { inland areas. }\end{array}$ \\
\hline $\begin{array}{l}\text { Service hot water EUI of } \\
\text { hospital, source kBtu/sf-yr }\end{array}$ & All & $\begin{array}{l}\text { Typical: } 35 \\
\text { Target: } 18\end{array}$ & $\begin{array}{l}\text { Based on } 79 \text { hospitals in CEUS, CA } \\
\text { statewide. }\end{array}$ \\
\hline $\begin{array}{l}\text { Ventilation EUI of } \\
\text { hospital, site kWh/sf-yr, }\end{array}$ & All & $\begin{array}{l}\text { Typical: } 7.5 \\
\text { Target: } 3.3\end{array}$ & $\begin{array}{l}\text { Based on } 79 \text { hospitals in CEUS, CA } \\
\text { statewide. }\end{array}$ \\
\hline \multicolumn{4}{|c|}{ ELECTRICAL END USE METRICS } \\
\hline $\begin{array}{l}\text { Lighting in patient room } \\
\text { area, site } \mathrm{kWh} / \mathrm{sf}-\mathrm{yr}\end{array}$ & All & $\begin{array}{l}\text { Typical: } 4.4 \\
\text { Target: } 3.0\end{array}$ & $\begin{array}{l}\text { Based on } 50 \text { nursing homes in } \\
\text { CEUS, CA statewide. }\end{array}$ \\
\hline
\end{tabular}

1 "Typical" corresponds to performance at roughly the median or mode of the distribution, "target" corresponds roughly to performance better than $80 \%$ of the comparison group of California hospitals; based on CEUS estimates.

Table 7. Efficiency benchmarks for thermal and ventilation systems.

\begin{tabular}{|l|c|c|l|}
\hline Metric & Region & Benchmarks $^{\mathbf{1}}$ & Source \& notes \\
\hline \multicolumn{2}{|l|}{ THERMAL AND VENTILATION SYSTEM EFFICIENCIES } \\
\hline $\begin{array}{l}\text { Cooling system overall } \\
\text { efficiency, site kW/ton }\end{array}$ & All & $\begin{array}{c}\text { Typical: } 0.8 \\
\text { Target: } 0.7\end{array}$ & $\begin{array}{l}\text { Based on expert recommendation } \\
\text { (water cooled systems) }\end{array}$ \\
\hline $\begin{array}{l}\text { Ventilation efficiency, } \\
\text { SUPPLY airflow W/cfm }\end{array}$ & All & $\begin{array}{c}\text { Typical: } 0.93 \\
\text { Target: } 0.75\end{array}$ & $\begin{array}{l}\text { Based on 158 air handlers at 44 CA } \\
\text { hospitals in CEUS }\end{array}$ \\
\hline $\begin{array}{l}\text { Ventilation efficiency, } \\
\text { RETURN airflow W/cfm }\end{array}$ & All & $\begin{array}{c}\text { Typical: } 0.5 \\
\text { Target: } 0.3\end{array}$ & $\begin{array}{l}\text { Based on 77 air handlers at 31 CA } \\
\text { hospitals in CEUS }\end{array}$ \\
\hline
\end{tabular}


Table 8. Hospital energy performance metrics requiring benchmarks.

\begin{tabular}{|c|c|}
\hline Metric & Comments \\
\hline \multicolumn{2}{|c|}{ THERMAL AND VENTILATION SERVICES PROVIDED TO HOSPITAL BUILDING } \\
\hline $\begin{array}{l}\text { Cooling to hospital } \\
\text { - Annual kBtu/sf-yr } \\
\text { - Base Btu/sf-day } \\
\text { - Hourly kBtu vs. outdoor temp. }\end{array}$ & $\begin{array}{l}\text { Base measured during neutral weather. } \\
\text { Pending data collection and analysis. }\end{array}$ \\
\hline $\begin{array}{l}\text { Heating to hospital } \\
\text { - Same metrics as cooling }\end{array}$ & Same as above. \\
\hline $\begin{array}{l}\text { Domestic hot water (DHW) to } \\
\text { hospital (kBtu/sf-yr) }\end{array}$ & $\begin{array}{l}\text { Pending data collection and analysis. } \\
\text { Assume to be similar each week. }\end{array}$ \\
\hline $\begin{array}{l}\text { Ventilation supply airflow: } \\
\text { - Base } \mathrm{cfm} / \mathrm{sf} \quad-\text { Peak cfm/sf }\end{array}$ & $\begin{array}{l}\text { Base for occupant and process loads; peak for seasonal } \\
\text { cooling increase with VAV systems. Pending data. }\end{array}$ \\
\hline \multicolumn{2}{|c|}{ THERMAL AND VENTILATION SYSTEM EFFICIENCIES } \\
\hline $\begin{array}{l}\text { Heating \& DHW system efficiencies: } \\
\text { - Source kBtu / kBtu to hospital }\end{array}$ & Pending data collection and analysis. \\
\hline $\begin{array}{l}\text { Heating water boiler efficiency: } \\
-\mathrm{kBtu} \text { out } / \mathrm{kBtu} \text { in }\end{array}$ & Base on available equipment. \\
\hline $\begin{array}{l}\text { Steam boiler efficiency: } \\
\text { - kBtu out / kBtu in }\end{array}$ & Base on available equipment. \\
\hline \multicolumn{2}{|l|}{ ELECTRICAL END USE METRICS } \\
\hline $\begin{array}{l}\text { Non-equipment electric EUI of hosp. } \\
\text { - Site kWh/sf-yr }\end{array}$ & Pending data collection and analysis. \\
\hline $\begin{array}{l}\text { Electrical EUI of patient room area } \\
\text { - Site } \mathrm{kWh} / \mathrm{sf}-\mathrm{wk}\end{array}$ & Pending data collection and analysis. \\
\hline $\begin{array}{l}\text { Non-equipment electrical EUI, D\&T } \\
\text { - Site kWh/sf-wk }\end{array}$ & Pending data collection and analysis. \\
\hline $\begin{array}{l}\text { Lighting power in patient room area } \\
\text { - Installed W/sf }\end{array}$ & Base on IESNA standards. \\
\hline Illumination in patient room area: $\mathrm{fc}^{3}$ & Base on IESNA standards. \\
\hline $\begin{array}{l}\text { Medical equipment, plug loads of } \\
\text { patient room areas: Site kWh/sf-wk }\end{array}$ & Pending data collection and analysis. \\
\hline $\begin{array}{l}\text { Energy intensity of large medical } \\
\text { equipment: } \\
\text { - Site kWh/yr } \\
\text { - Site kWh/unit activity }\end{array}$ & Pending data collection and analysis. \\
\hline
\end{tabular}

\section{CEUS end-use estimates used to derive benchmarks}

The following figures were produced by a demo version of LBNL's EnergyIQ non-residential energy benchmarking web site, using results of simulation models of CEUS buildings. ${ }^{8}$ Cooling site energy intensity for California coastal hospitals (median is 4.5):

\footnotetext{
${ }^{8}$ http://energyiq.lbl.gov/benchmark.html
} 


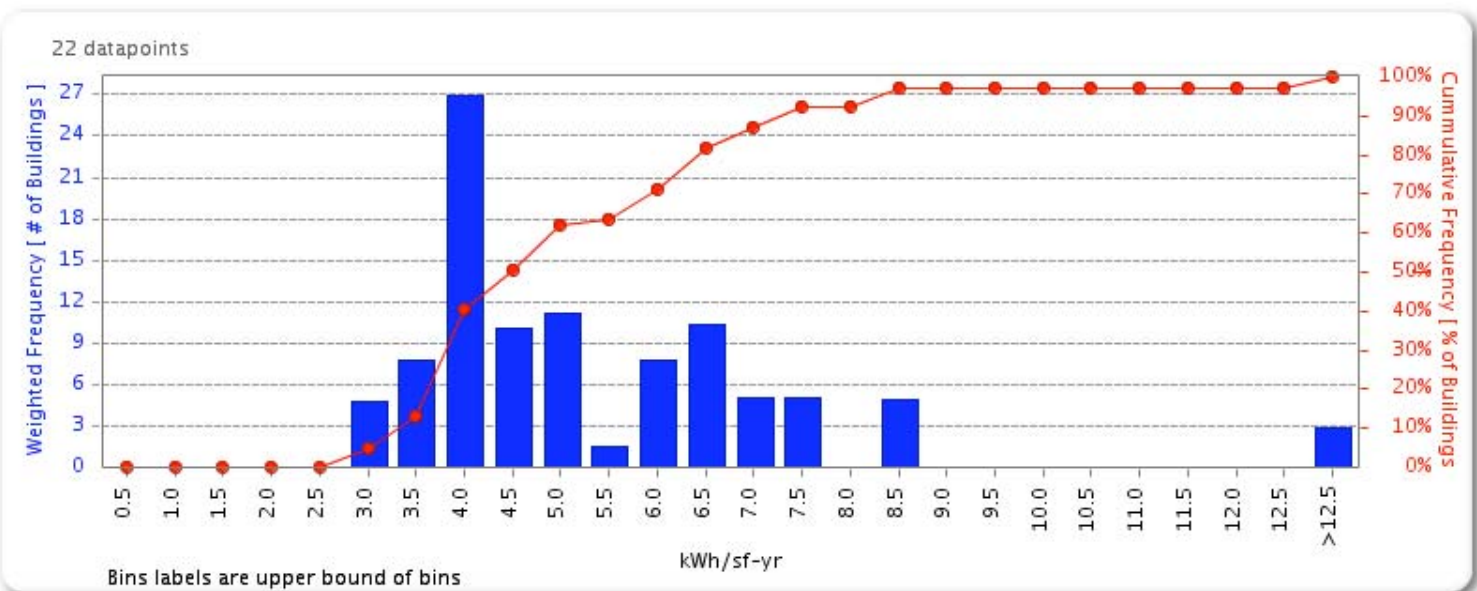

Cooling site energy intensity for California inland hospitals (median is 6.6):

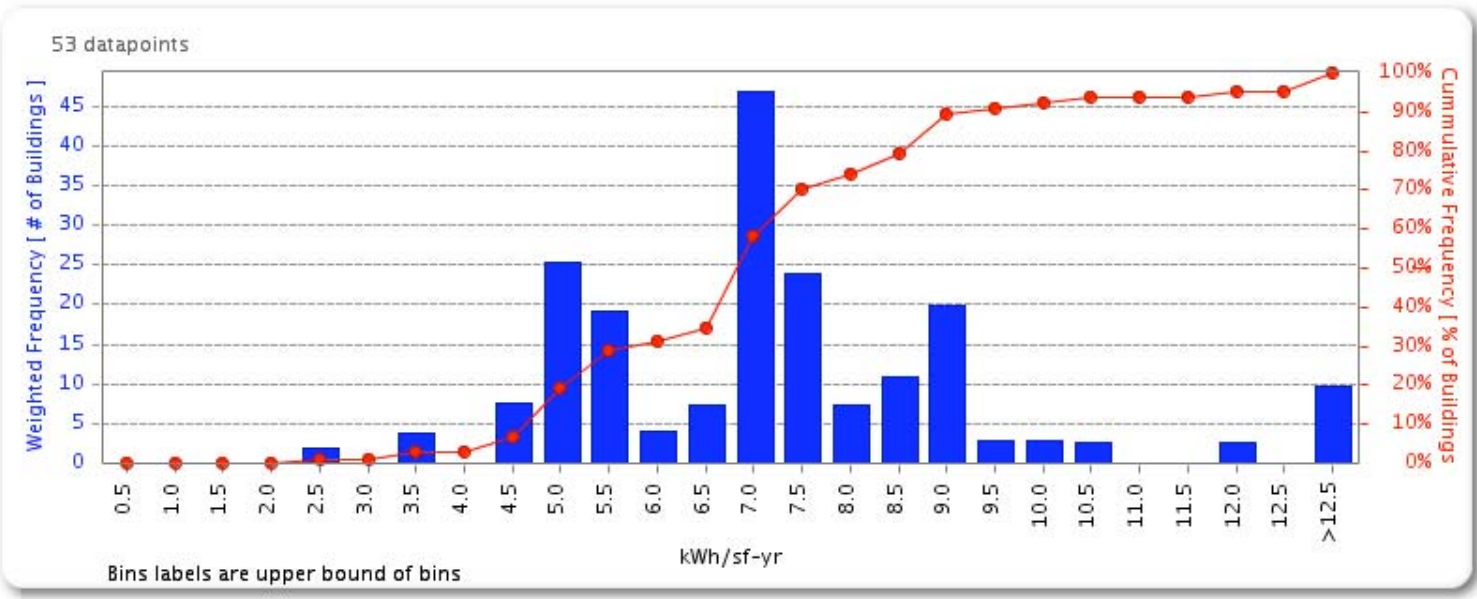

Cooling site energy intensity for California mountain hospitals:

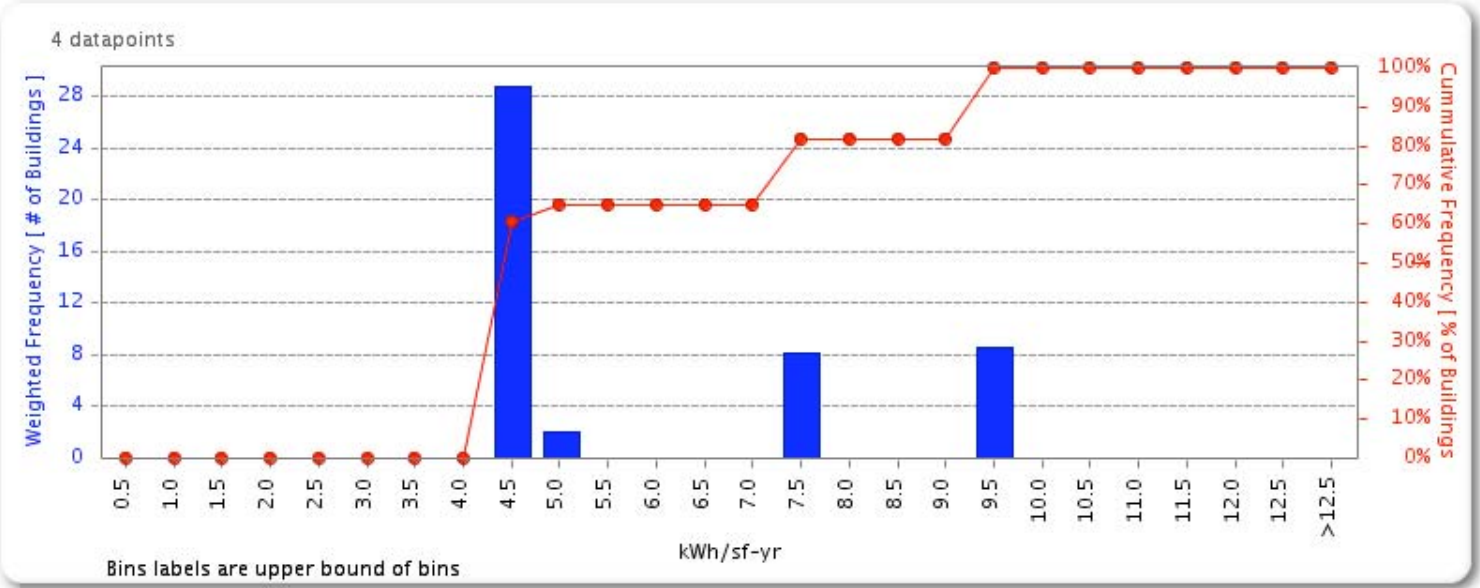

Figure 1. CEUS estimates for site energy intensity of California hospitals ${ }^{9}$.

\footnotetext{
${ }^{9}$ Plots produced by EnergyIQ benchmarking tool: http://energyiq.lbl.gov/benchmark.html
} 
Cooling source energy intensity for California coastal hospitals (median is 44.0):

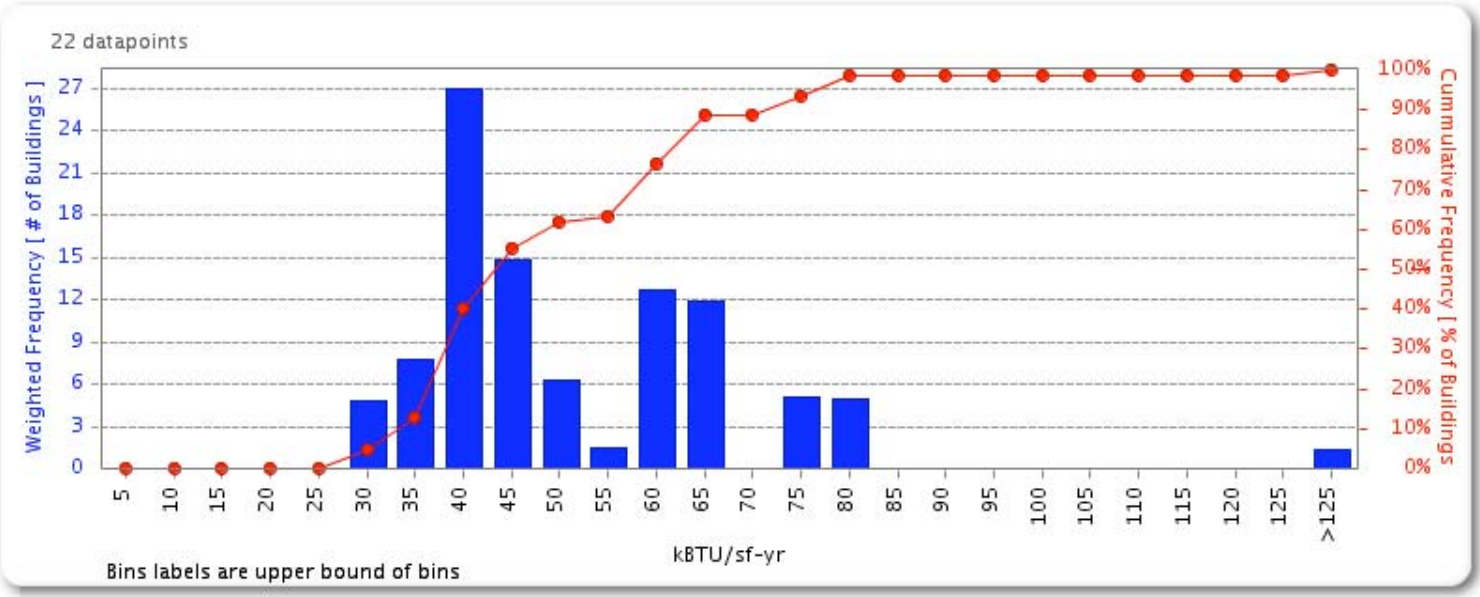

Cooling source energy intensity for California inland hospitals (median is 65):

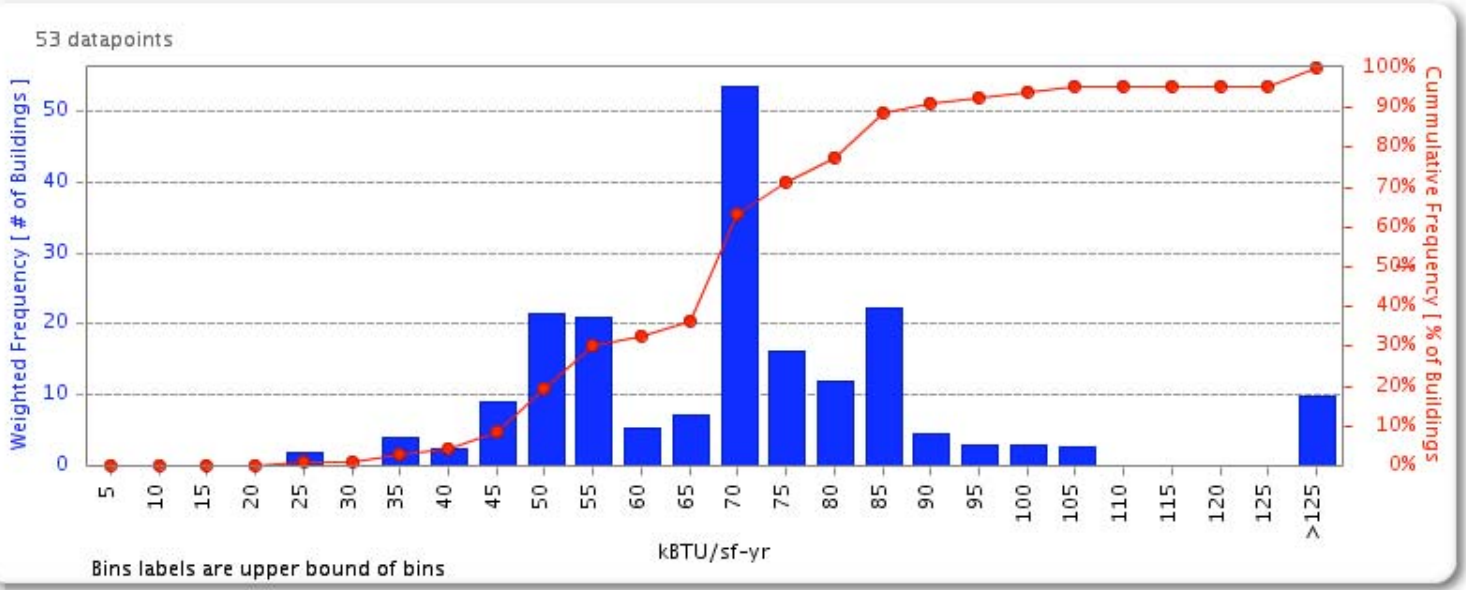

Cooling source energy intensity for California mountain hospitals:

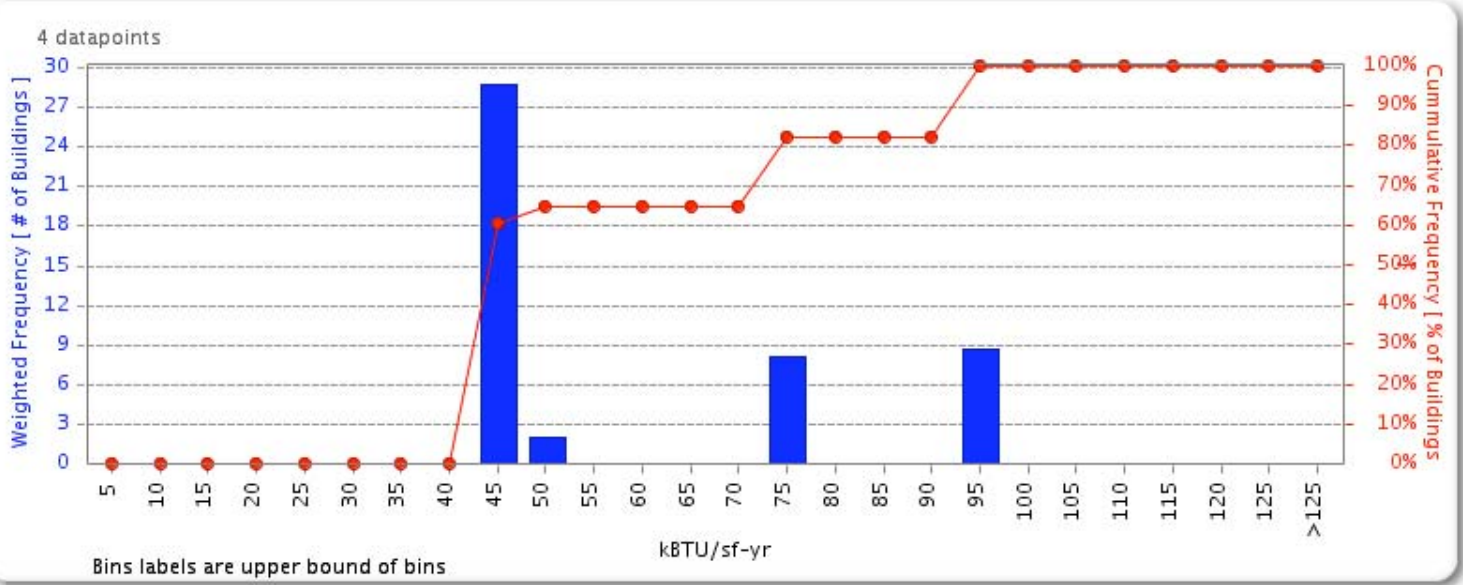

Figure 2. CEUS estimates for cooling source energy intensity of California hospitals ${ }^{10}$.

\footnotetext{
${ }^{10}$ Plots produced by EnergyIQ benchmarking tool: http://energyiq.lbl.gov/benchmark.html
} 
Space heating source energy intensity for California coastal hospitals (median is 96).

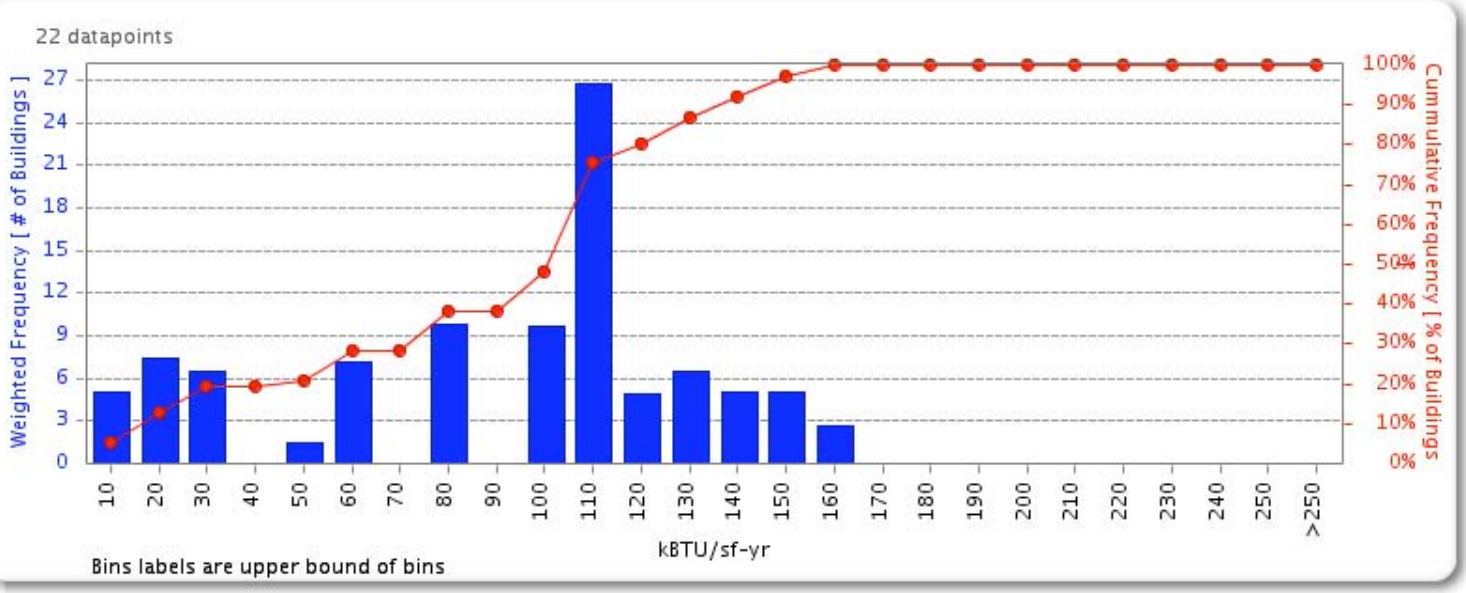

Space heating source energy intensity for California inland hospitals (median is 81).

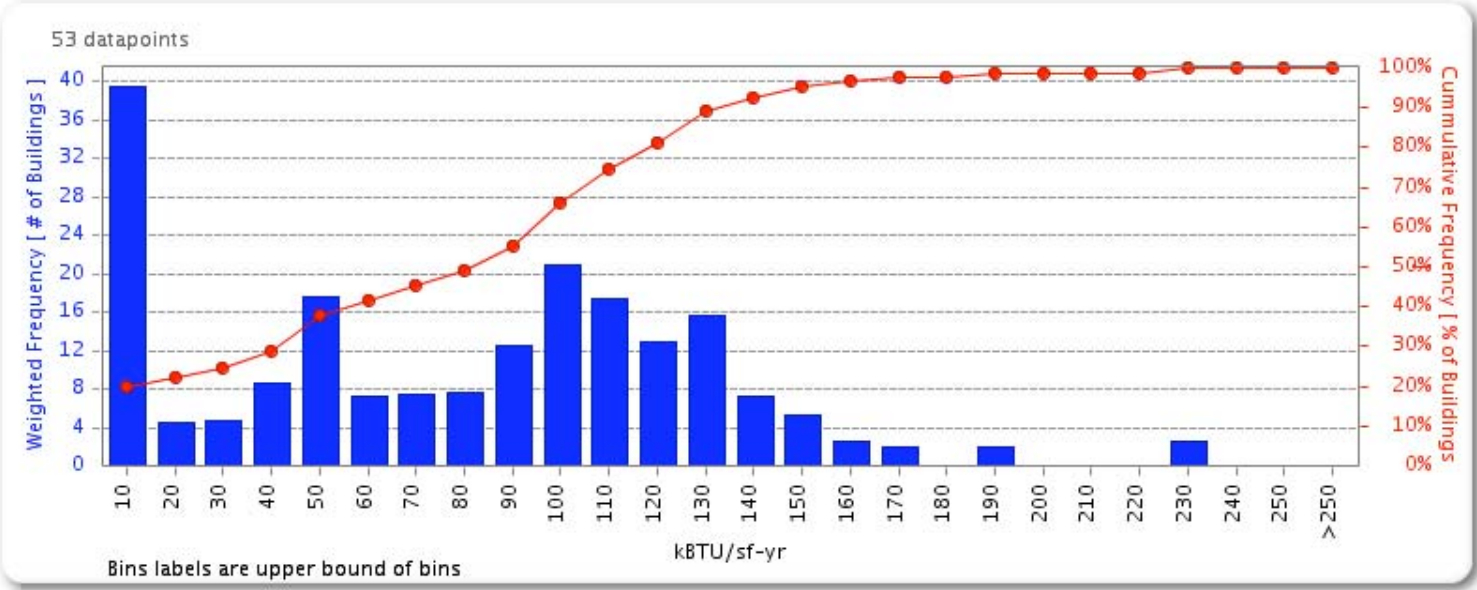

Space heating source energy intensity for California mountain hospitals.

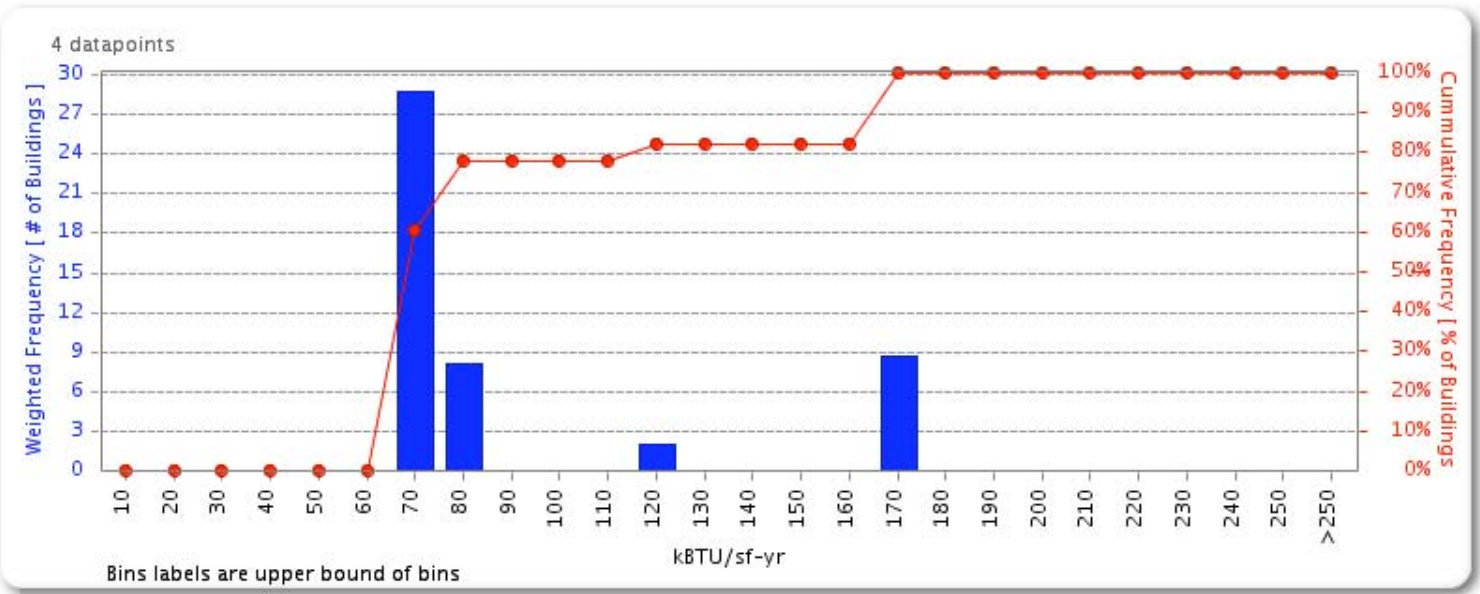

Figure 3. CEUS estimates for heating source energy intensity of California hospitals ${ }^{11}$.

\footnotetext{
${ }^{11}$ Plots produced by EnergyIQ benchmarking tool: http://energyiq.lbl.gov/benchmark.html
} 
Service water heating source energy intensity for California coastal hospitals (median is 29.5).

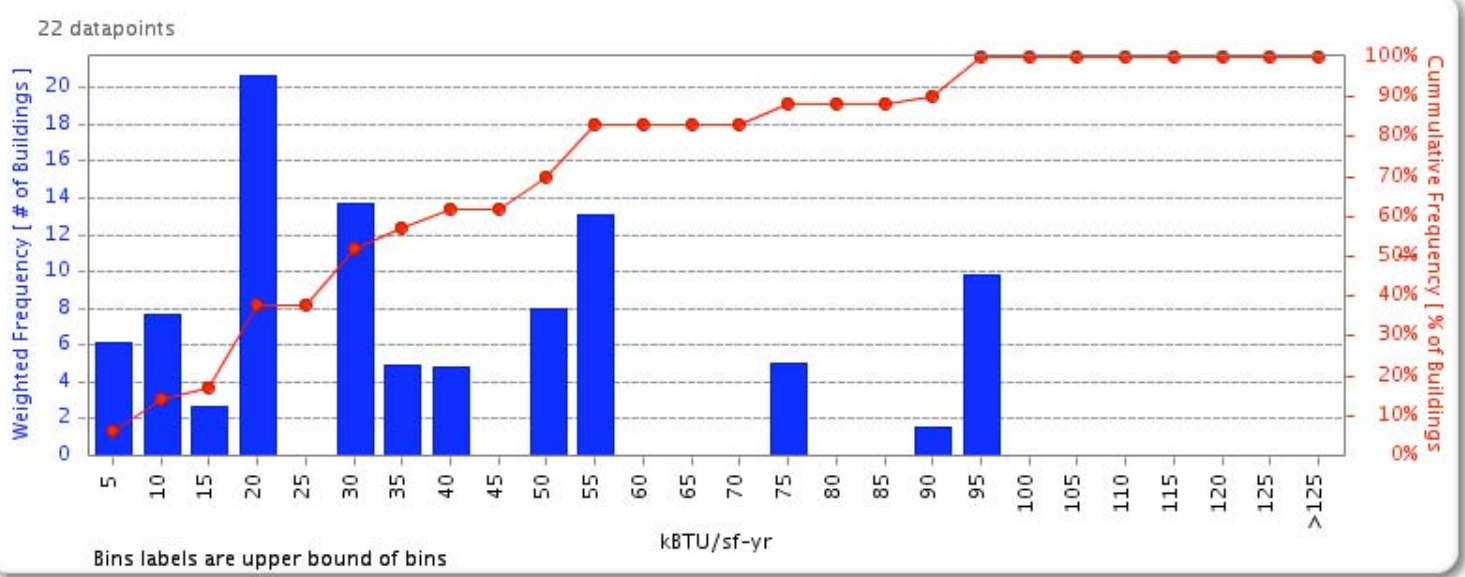

Service water heating source energy intensity for California inland hospitals (median is 32.8).

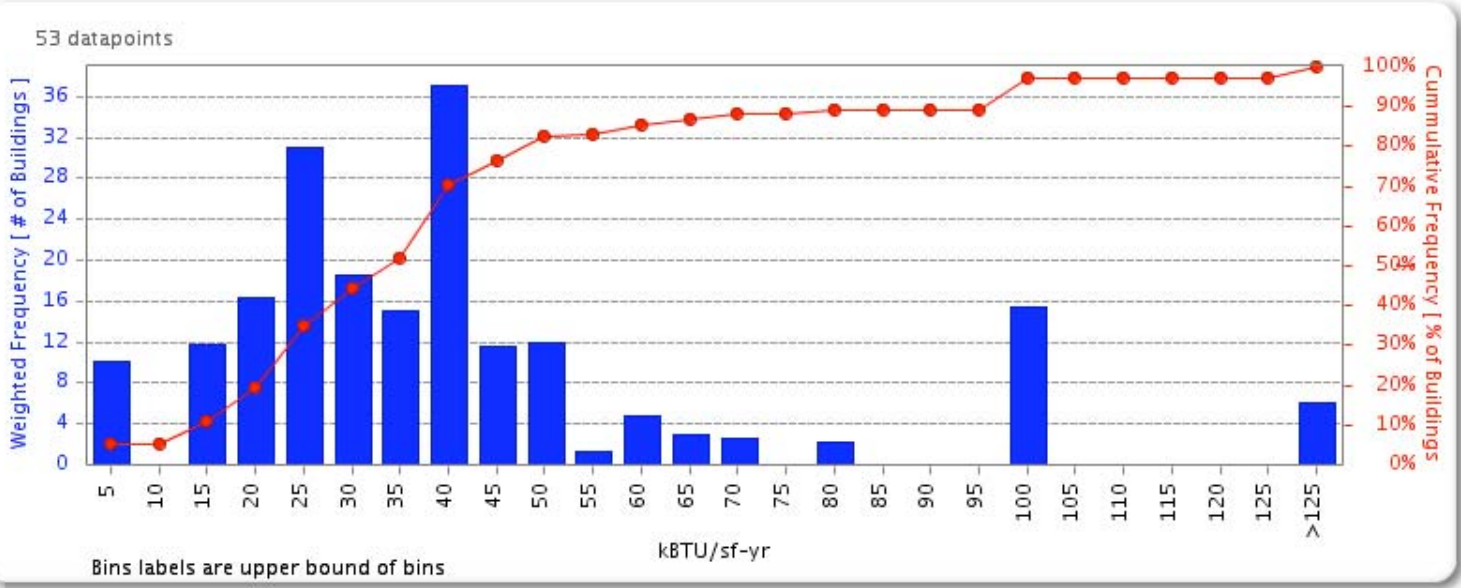

Service water heating source energy intensity for all California hospitals (median is 35.6):

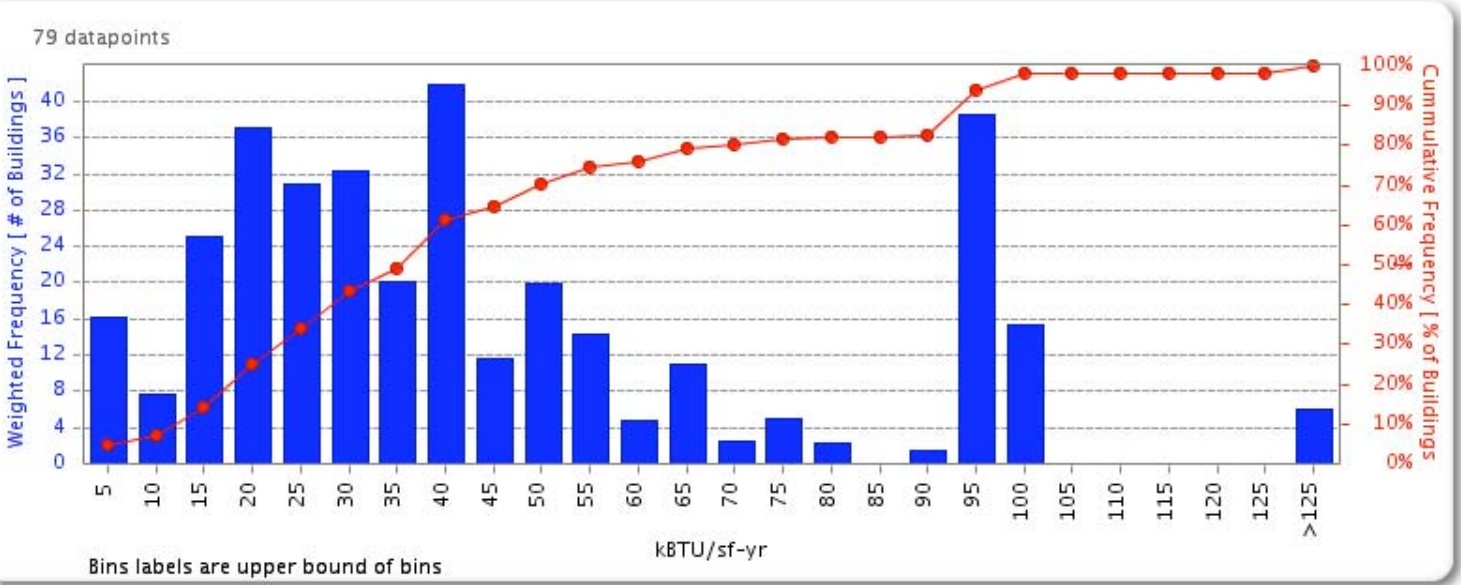

Figure 4. CEUS estimates for DHW $\underline{\text { source energy intensity of California hospitals }}{ }^{12}$.

\footnotetext{
${ }^{12}$ Plots produced by EnergyIQ benchmarking tool: http://energyiq.lbl.gov/benchmark.html. Two of the four mountain hospitals (not included in first 2 figures) has service water EUIs in the $\leq 95 \mathrm{kBtu} / \mathrm{sf}-\mathrm{yr}$ bin.
} 
Ventilation site energy intensity for California coastal hospitals (median is 5.9).

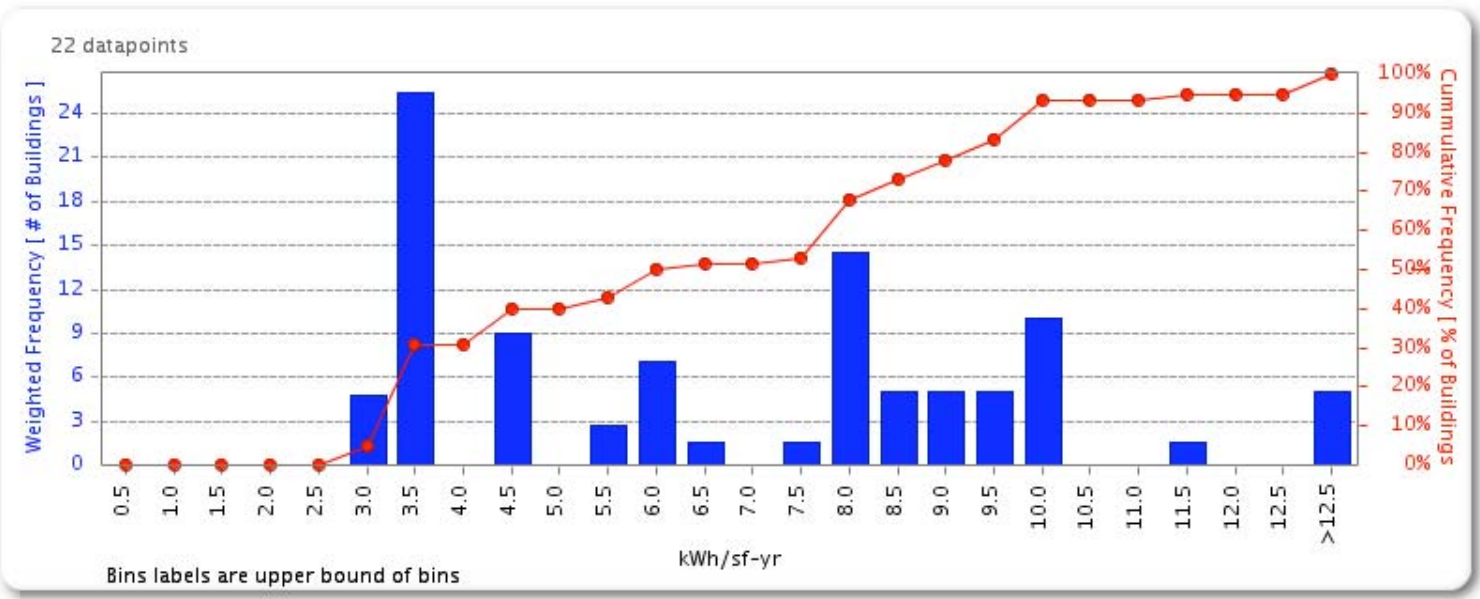

Ventilation site energy intensity for California inland hospitals (median is 8.3).

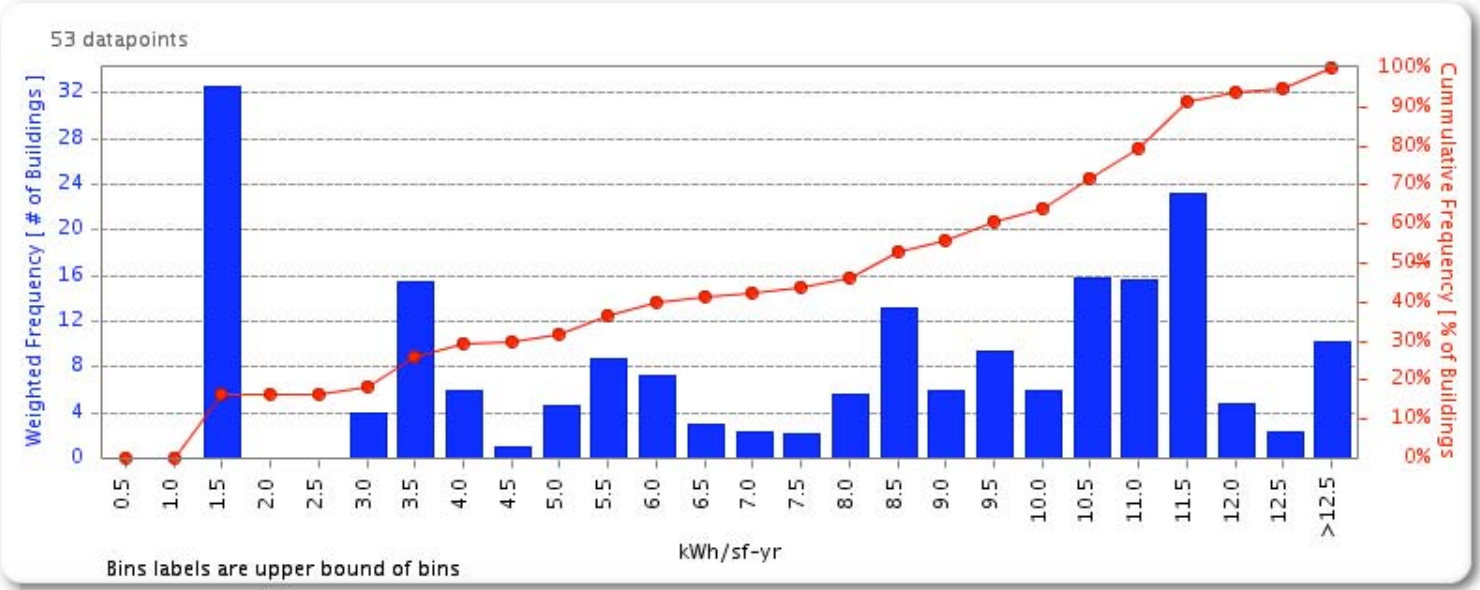

Ventilation site energy intensity for all California hospitals (median is 7.5)

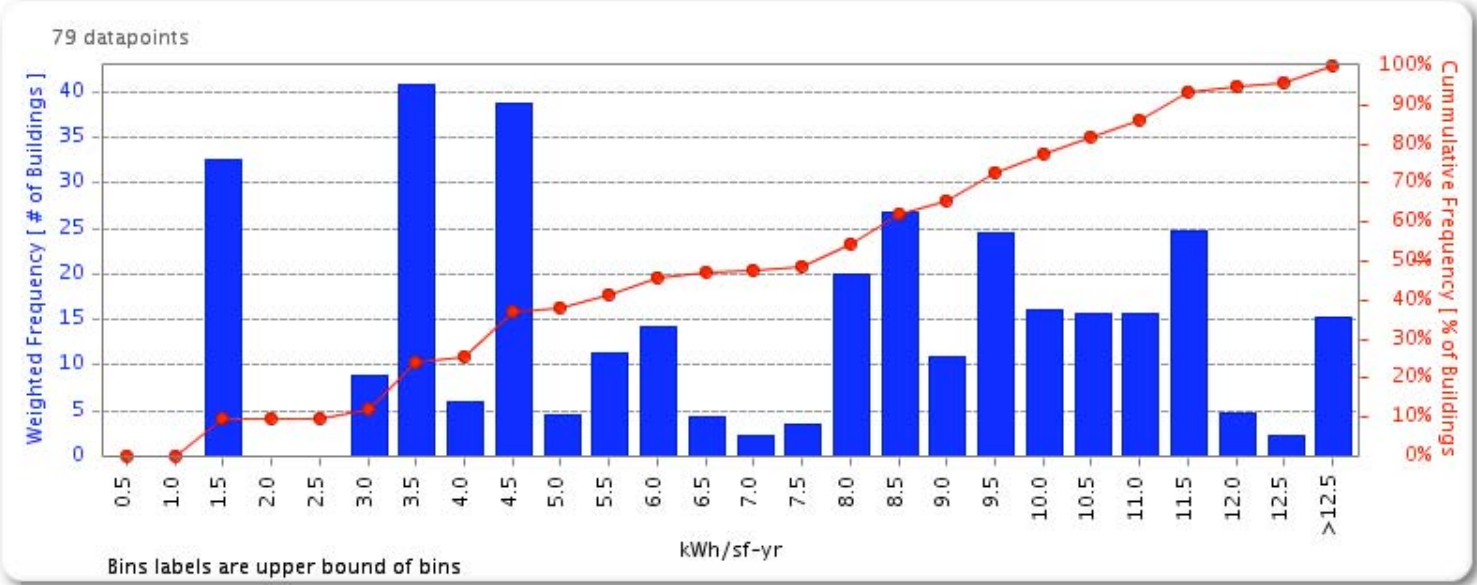

Figure 5. CEUS estimates for ventilation site energy intensity of California hospitals ${ }^{13}$.

\footnotetext{
${ }^{13}$ Plots produced by EnergyIQ benchmarking tool: http://energyiq.lbl.gov/benchmark.html.
} 
Lighting site energy intensity for all California nursing homes (median is 4.5).

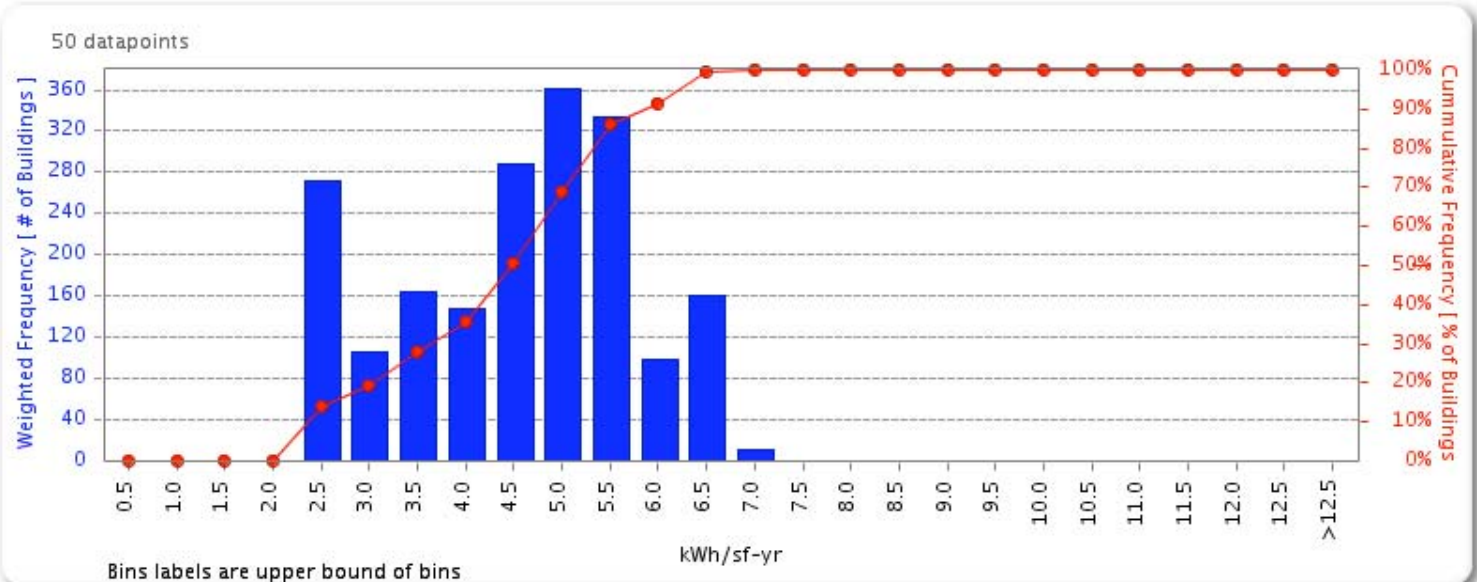

Figure 6. CEUS estimates for lighting site energy intensity of California nursing homes ${ }^{14}$.

Supply airflow W/cfm for California hospitals

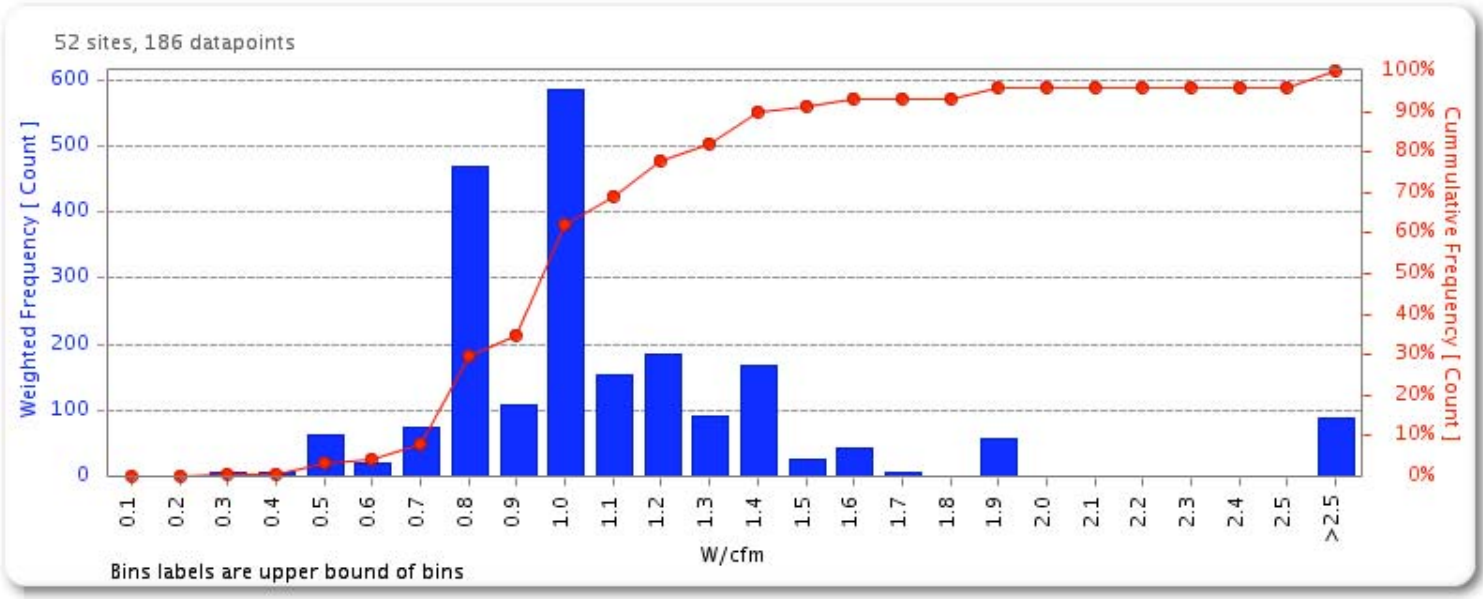

Return airflow W/cfm for California hospitals

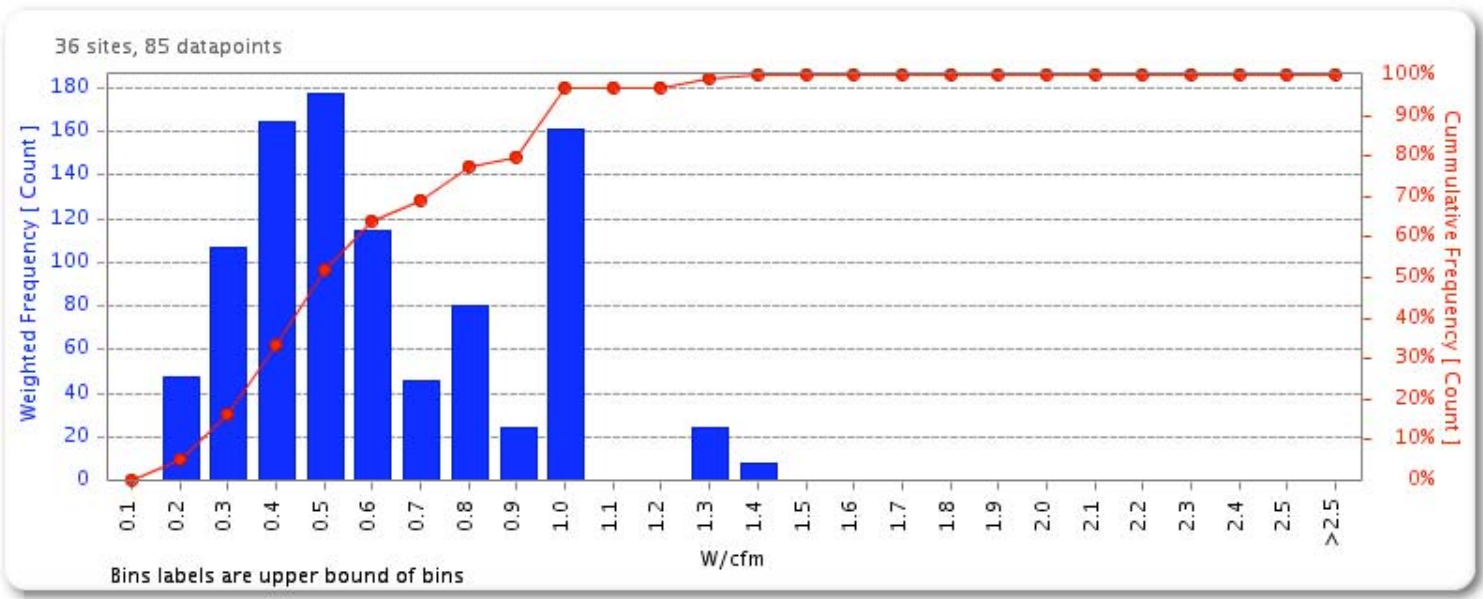

Figure 7. CEUS estimates of ventilation efficiencies for California hospitals.

\footnotetext{
${ }^{14}$ Plots produced by EnergyIQ benchmarking tool: http://energyiq.lbl.gov/benchmark.html.
} 